(c) 2016, Elsevier. Licensed under the Creative Commons Attribution-NonCommercial-NoDerivatives 4.0 International

http://creativecommons.org/licenses/by-nc-nd/4.0/

\title{
Developing Real Option Game Models
}

\author{
Alcino Azevedo ${ }^{1,2 *}$ and Dean Paxson** \\ *Hull University Business School \\ Cottingham Road, Hull HU6 7RX, UK \\ **Manchester Business School \\ Booth Street West, Manchester M15 6PB, UK
}

\begin{abstract}
By mixing concepts from both game theoretic analysis and real options theory, an investment decision in a competitive market can be seen as a "game" between firms, as firms implicitly take into account other firms' reactions to their own investment actions. We review two decades of real option game models, suggesting which critical problems have been "solved" by considering game theory, and which significant problems have not been yet adequately addressed. We provide some insights on the plausible empirical applications, or shortfalls in applications to date, and suggest some promising avenues for future research.
\end{abstract}

Keywords: Finance, Real Option Games, Investment Analysis, Strategic Investment.

\footnotetext{
${ }^{1}$ Corresponding author: a.azevedo@hull.ac.uk (A. Azevedo), dean.paxson@mbs.ac.uk (D. Paxson).

${ }^{2}$ We gratefully acknowledge helpful comments on earlier versions from Roger Adkins, David Cardoso, Michael Flanagan, Peter Hammond, Wilson Koh, David Nicolaus, Paulo Pereira, Helena Pinto, Artur Rodrigues, Jacco Thijssen, Lenos Trigeorgis, Martin Walker, and the participants at the Real Options Conference, Rome, 2010, the European Financial Management Association Conference, Braga, 2011, and the Portuguese Finance Network Conference, Aveiro, 2012. Alcino Azevedo gratefully acknowledges financial support from Fundação Para a Ciência e a Tecnologia.
} 


\section{Introduction}

Investment in competitive markets is a "game" among firms, since in making investment decisions, firms implicitly take into account what they think will be the other firms' reactions to their own investment actions, and realize that their competitors think the same way. Consequently, as game theory aims to provide an abstract framework for modeling situations involving interdependent choices, and "real options" ("RO") theory is appropriate for most investment decisions, a combination of these two theories have yielded promising results.

A "standard real option game" ("SROG") model is where the value of the investment is treated as a state variable that follows a known process $^{3}$; time is considered infinite and continuous; the investment cost is sunk, indivisible and known $^{4}$; firms are not financially constrained; the investment problem is studied in isolation as if it is the only asset on the firm's balance sheet (i.e., the game is played on a single project); and there are usually two firms holding the option to invest ${ }^{5}$. The focus is the derivation of the firms' value functions and their respective investment thresholds, under the assumption that either firms are risk-neutral or the stochastic evolution of the variable(s) underlying the investment value is spanned by the current instantaneous returns from a portfolio of securities that can be traded continuously without transaction costs in a perfectly competitive capital market.

The two most common investment games are the "pre-emption game" (PE) and the "war-ofattrition game" (WOA), both usually formulated as "zero-sum games" (i.e., firms can only improve their profits by reducing the profits of rivals). In the PE, it is assumed that there is a "first-mover advantage" ("FMA") that gives firms an incentive to be the first to invest. In the attrition game, it is assumed that there is a second-mover advantage that gives firms an incentive to be the second to invest. Typically the advantage of investing first/second is assumed to be limited ${ }^{6}$, so the investment of the leader (PE) or the follower (WOA) does not completely eliminate the revenues of its rival. The investment game is treated as a "one-shot" game (i.e., firms are allowed to invest only once); firms invest either sequentially or simultaneously, or both; cooperation between firms is not allowed; the market for the project, underlying the investment decision, is considered to be complete and frictionless; and firms are assumed to be ex-ante (i.e., before the investment) and expost (i.e., after the investment) symmetric.

\footnotetext{
${ }^{3}$ Typically, geometric Brownian motion $(\mathrm{gBm})$ and mean reverting processes, stochastic processes with jumps, birth and death processes, or combinations of these processes.

${ }^{4}$ Some authors relax this assumption, such as Dixit and Pindyck (1994), chapter 6, and Azevedo and Paxson (2011) where the investment cost follows a $\mathrm{gBm}$ process.

${ }^{5}$ See Bouis et al. (2009) for an example of a RO model with three firms.

${ }^{6}$ Exceptions to this rule are Williams (1993) and Murto and Keppo (2002) models, derived for a context of complete preemption.
} 
In models where the RO value is driven by just one stochastic underlying variable, the firm's optimal investment timing is defined by a point; in models that use two stochastic underlying variables, by a line; and in models that use three or more stochastic underlying variables, by a surface or other more complex space structures. However, regardless of the number of underlying variables used, the principle remains the same: "a firm should invest as soon as its investment threshold is crossed the first time". "Non-standard real options games" ("NSROG") relax some of these assumptions and constraints ${ }^{7}$.

The three most basic elements that characterize a game are the players, their strategies and payoffs. Translating these to a "real option game" ("ROG"), the players are the firms that hold the option to invest, the strategies are the choices "invest"/"defer" and the payoffs are the firms' value functions. Additionally, to be fully characterized, a game still needs to be specified in terms of what sort of information (complete/incomplete, perfect/imperfect, symmetric/asymmetric) the players have at each instant. Also required are what type of game is being played (a "one-shot" game, a "zero-sum" game, a sequential/simultaneous game, or a cooperative/non-cooperative game); and whether mixed strategies are allowed.

One difference between a "standard game" ("SG") from game theory and a SROG is in the way the players' payoffs are given. In SG such as the "prisoners' dilemma", the "grab-the-dollar", the "burning the bridge" or the "battle-of-the-sexes", the players' payoffs are usually deterministic, while in SROG they are given by sometimes complex mathematical functions that depend on one, or more, stochastic underlying variables ${ }^{8}$. This fact changes radically the rules under which the game equilibrium is determined, because if the players' payoffs depend on time, and time is continuous, the game is played in continuous-time. But, if the game is played in a continuous-time and players can move at any time, what does the strategy "move immediately after" mean? In the RO literature, the approach used to overcome this problem is usually based on Fudenberg and Tirole (1985) - F\&T (1985) - who develop a new formalism for modeling deterministic timing games and introduce the "principle of rent equalization" for pre-emption games, a methodology which was extended to stochastic ROG ${ }^{9}$.

The main principle underlying game theory is that those involved in strategic decisions are affected not only by their own choices but also by the decisions of others. Once the structure of a game and

\footnotetext{
${ }^{7}$ Models that use more than one stochastic underlying variable are defined here as NSROG.

${ }^{8}$ In SROG the game "payoffs" are denoted "value functions".

${ }^{9}$ Sometimes without a proper consideration of its appropriateness, as highlighted by Thijssen et al. (2012) -see discussion in section 2.2.
} 
the strategies of the players are set, the equilibrium of the game can be determined using Nash $(1950,1953)^{10}$.

We cite an extensive number of papers, published or in progress, modeling investment decisions considering uncertainty and competition. Our goal is to organize two decades of literature on ROG models into "game-theoretic categories", a unique contribution in the literature, giving particular emphasis to the models underlying game-theoretic aspects in terms of what has been accomplished, relating the accomplished results to the known empirical evidence and industry applications, if any ${ }^{11}$. There is a consensus among researchers that it might be possible to develop more sophisticated ROG through a better integration between real options and game theory. We suggest new avenues for future research, partly based on perceived (game-theoretic related) gaps in the literature $^{12}$.

This paper is organized as follows. In section 2, we introduce basic aspects of the SROG models, discuss the mathematical formulation, principles and methodologies commonly used to derive the firms' value functions (payoffs) and investment thresholds, and introduce and contrast the discretetime and the continuous-time frameworks when applied to ROG. Section 3 reviews two decades of academic research on "standard" and "non standard" ROG. Section 4 surveys the limited empirical research and suggests some testable hypotheses. Section 5 concludes and suggests new avenues for research.

\section{SROG Framework}

Consider an industry comprised of two (ex-ante/ex-post) identical firms, possessing an option to invest in the same (and unique) project that will produce a unit of output. The irreversible investment cost is $I$ and the cash flow stream from the investment is uncertain. The payoff of each firm is affected by the actions (strategy) of its rival ${ }^{13}$. The price unit of output, $P(t)$ fluctuates stochastically over time according to equation (1),

$$
P(t)=X(t) D[Q(t)]
$$

\footnotetext{
${ }^{10}$ When competing for the revenues from an investment, if firms reach a point where there is a set of strategies with the property that no firm can benefit by changing its strategy while its opponent keeps its strategies unchanged, then that set of strategies, and the corresponding firms' payoffs, constitute a Nash equilibrium.

${ }^{11}$ Huisman et al. (2004) and Chevalier-Roignant and Trigeorgis (2011) are also literature reviews of RO models. While we focus mainly on the game theoretic aspects underlying RO models and provide full game-theoretic classification for the selected articles, Huisman et al. (2004) focus mainly on continuous-time lumpy problems, and Chevalier-Roignant and Trigeorgis (2011) are more centered on other modeling aspects of RO models such as myopic investment behavior, incremental capacity expansion and demand shocks.

${ }^{12}$ We provide in the Appendix full game-theoretic characterization for each article reviewed.

${ }^{13}$ In the extreme case, as soon as one firm invests, the investment becomes worthless for the other firm.
} 
where, $D[Q(t)]$ is the inverse demand function, with $Q(t)$ representing the industry supply process. The market supply has three states, $Q(t)=0, Q(t)=1$ and $Q(t)=2$, for the scenarios where both firms are idle, only the leader is active and both firms are active, respectively. The inverse demand function is downward sloping $\left(D^{\prime}[Q(t)]<0\right)$, which ensures a FMA; and $X(t)$ is an exogenous shock process to demand following a $\mathrm{gBm}$ process given by Equation (2).

$$
d X=\mu_{X} X d t+\sigma_{X} X d z
$$

where, $\mu_{X}$ is the instantaneous conditional expected percentage change in $X$ per unit of time; $\sigma_{X}$ is the instantaneous conditional standard deviation per unit of time; and $d z$ is the increment of a standard Wiener process for the variable $X$.

At the beginning of the investment game each firm contemplates two choices, whether it should be the first to exercise the option (becoming the leader) or the second to exercise (entering the market as a follower), having for each of these strategies an optimal time to act. The equilibrium set of exercise strategies is derived by letting the firms choose their roles and deriving the value functions of both firms, starting with the follower's value function and then working backwards in a dynamic programming fashion to determine the leader's value function.

Denoting $F_{F}(X)$ as the value of the follower before investing and assuming that firms are riskneutral, $F_{F}(X)$ must solve the following equilibrium differential equation:

$$
\frac{1}{2} \sigma_{X}{ }^{2} X^{2} \frac{\partial^{2} F_{F}(X)}{\partial X^{2}}+\mu_{X} X \frac{\partial F_{F}(X)}{\partial X}-r F_{F}(X)=0
$$

The differential equation (3) must be solved subject to the boundary conditions (4) and (5), which ensure that the follower invests at a moment where its "option to invest" is maximized:

$$
\begin{gathered}
F_{F}\left(X_{F}^{*}\right)=\frac{X_{F}^{*} D(2)}{r-\mu_{x}}-I \\
F_{F}^{\prime}\left(X_{F}^{*}\right)=\frac{D(2)}{r-\mu_{x}}
\end{gathered}
$$

where, $X_{F}^{*}$ is the value of $X(t)$ that triggers entry. For convergence of the solution we assume that $\delta_{x}=\left(\mu_{x}-r\right)>0$, where $r$ is the riskless interest rate, and both the leader and follower have the same $I$.

The follower should invest the first time $X(t) \geq X_{F}^{*}$. The boundary condition (4) is the value-matching condition. It states that at the moment the follower's option is exercised its net payoff is $X_{F}^{*} D(2) /\left(r-\mu_{X}\right)-I$ (the discounted expected present value of the follower's share of the duopoly cash flow in perpetuity). The boundary condition (5) is called the "smooth-pasting" or "highcontact" condition, and ensures that the exercise trigger is chosen to maximize the value of the option. Through this procedure we get closed-form solutions for the leader's and the follower's 
value functions, $F_{F}(X)$ and $F_{L}(X)$, respectively equations (8) and (6), and for the follower's investment threshold, $X_{F}^{*}$, equation (7)

$$
\begin{gathered}
F_{F}(X)= \begin{cases}\frac{I}{\beta-1}\left(\frac{X}{X_{F}^{*}}\right)^{\beta} & \text { if } X<X_{F}^{*} \\
\frac{X D(2)}{r-\mu_{X}}-I & \text { if } X \geq X_{F}^{*}\end{cases} \\
X_{F}^{*}=\left(\frac{\beta}{\beta-1}\right)\left(\frac{r-\mu_{X}}{D(2)}\right) I \\
F_{L}(X) \begin{cases}\frac{X D(1)}{r-\mu_{X}}-I+\frac{D(2)-D(1)}{D(2)} \frac{\beta}{\beta-1} I\left(\frac{X}{X_{F}^{*}}\right)^{\beta} & \text { if } X<X_{F}^{*} \\
\frac{X D(2)}{r-\mu_{X}} & \text { if } X \geq X_{F}^{*}\end{cases}
\end{gathered}
$$

where $D(2)<D(1)$ and $\beta_{1}$ is the positive root of the following quadratic function: $0.5 \sigma^{2} \beta(\beta-1)+(r-\delta) \beta-r=0$, given by equation (9):

$$
\beta_{1(2)}=\frac{1}{2}-\frac{(r-\delta)}{\sigma^{2}}+\sqrt{\left[\frac{(r-\delta)}{\sigma^{2}}-\frac{1}{2}\right]^{2}+\frac{2 r}{\sigma^{2}}}
$$

Using the "principle of rent equalization" of F\&T (1985), we derive the leader's investment threshold, $X_{L}^{*}$, equalizing, for $X<X_{F}^{*}$, expressions (6) and (8), and replacing in the resulting equation $X$ by $X_{L}^{*}$ and solving for $X_{L}^{*}$. Figure 1 illustrates the value functions of both firms and respective investment thresholds as a function of $x$.

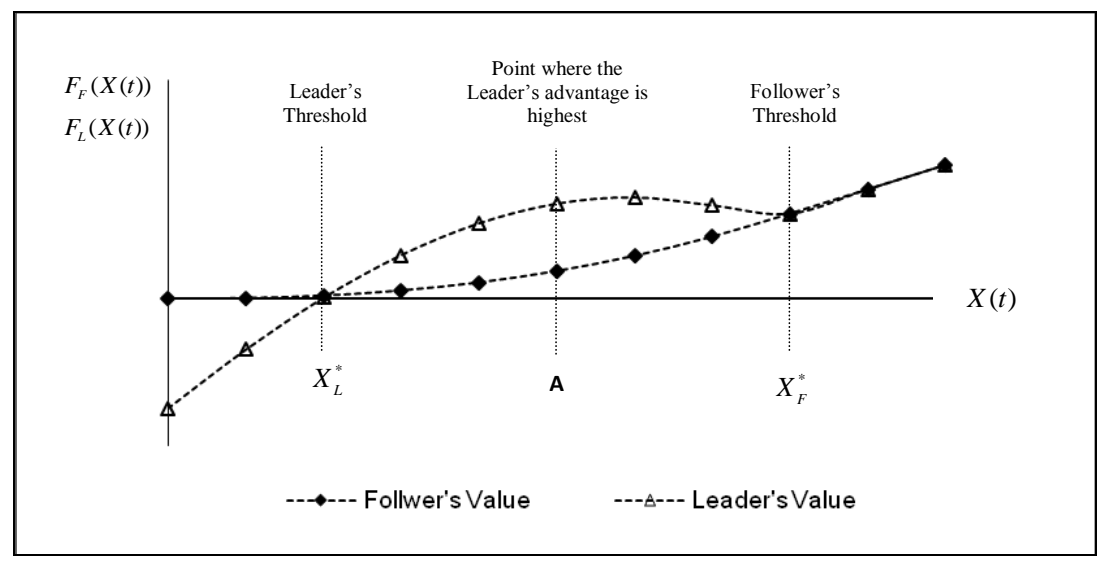

Fig. 1 - Value Functions of the Leader and the Follower for a Two-Firm Pre-emption Game

If both firms want to be the leader and invest at the same time, they will invest at the point where rents equalize, $X=X_{L}^{*}$, (the pre-emption trigger) where the value function of both firms cross the first time $^{14}$. Thereafter, they enjoy the duopoly cash flow in perpetuity, given by equation (10).

\footnotetext{
${ }^{14}$ There are ROG models for duopolies, such as Murto and Keppo (2002), where simultaneous investment is not allowed. In such cases, it is assumed that "if the two firms want to invest simultaneously, then the one with the highest value, $X$,
} 


$$
F_{L}(X)=F_{F}(X)=\frac{X \mathrm{D}(2)}{r-\mu_{X}}-I
$$

Following the approach above, sometimes with small adjustments in the underlying variable(s) and/or the competition setting, following Smets (1993) ${ }^{15}$, Dixit and Pindyck (1994, ch. 9), Huisman (2001), Paxson and Pinto (2005), and Pawlina and Kort (2006), among others, developed ROG models for leader-follower competition settings. With few exceptions, it is assumed that firms can observe all the parameters of the model (drift, volatility, etc) and the evolution of the random variable $d z$ given in equation (2).

\subsection{The pre-emption game}

The pre-emption game is one of the most common games in the ROG literature, usually formulated as a two-player game where time is continuous and the horizon of the game is infinite. RO theory shows that when an investor has a monopoly over an investment decision, with the investment cost irreversible and the expected revenues from the investment uncertain, there is an option value to wait which is an incentive to delay the investment more than the "net present value" ("NPV") methodology suggests. The more uncertain are the revenues, the more valuable is the option to defer the investment. However, when competition is added to the investment problem, ceteris paribus, the intuition is that the value of the option to wait tends to erode. The higher the competition between firms, the less valuable is the option to defer the investment.

In RO duopoly pre-emption games we use the F\&T (1985) principle of rent equalization, which advocates that the erosion in the value of the option to defer the investment is caused by the fact that each firm fears being pre-empted in the market by its rival due to the FMA. They use a twofirm deterministic game setting to optimize the adoption of a new technology to illustrate the effect of pre-emption in games of timing, and show that the threat of pre-emption equalizes rents.

Figure 1 above illustrates how this principle works, where we can identify three different regions on the $X(t)$ line: $\left[0, X_{L}^{*}\right),\left[X_{L}^{*}, X_{F}^{*}\right)$ and $\left[X_{F}^{*}, \infty\right)$. In the interval $\left[0, X_{L}^{*}\right)$ the payoff of the follower is higher than that of the leader, for $\left[X_{L}^{*}, X_{F}^{*}\right)$ the payoff of the leader is higher than that of the follower; for $\left[X_{F}^{*}, \infty\right)$ both firms have the same payoff. In addition, we can see that $\mathrm{A}$ is the point where the leader's advantage reaches a maximum. In absence of the pre-emption effect, the optimal time to invest for the leader is at point A. However, when there is a FMA, firms are afraid of being pre-

gets the project; if the project has the same value for both firms and both want to invest at the same time, the one who gets the project is chosen randomly using an even uniform distribution."

15 The first RO model considering competition was developed by Frank Smets in his PhD dissertation (1993), chapter 1, pp. 36-66, applied to a duopoly foreign direct investment decision. 
empted and so the leader invests at point $X_{L}^{*}$, where the payoffs (rents) from being the leader and the follower equalize.

Notice that, in the interval $\left(X_{L}^{*}, A\right]$ there are an infinite number of timing strategies that would lead to a better payoff for the leader than the strategy to invest at $X_{L}^{*}$. However, when the two firms have perfect, complete and symmetric information about the game, both know that in the interval $\left(X_{L}^{*}, A\right]$ if they invest an instant before the opponent they will get a payoff advantage, and this competition to pre-empt the rival leads both firms to target their investment at point $X_{L}^{*}$, where each firm has a 50 percent chance of being the leader. As soon as one firm achieves the leadership in the investment, for the follower, the optimal time to invest is point $X_{F}^{*}$. After the follower investment both firms share the market revenues in a (deterministic) pre-assigned way.

In Figure 1 the value functions of the leader and the follower overlap each other for $\left[X_{F}^{*}, \infty\right)$, i.e., after the follower invests, both firms share a (permanent) symmetric market share where the initial FMA is completely eliminated. However, the framework above allows other deterministic ex-post market share arrangements where a certain (temporary or permanent) FMA is kept. In this later case, the leader's value function would be parallel to and above the follower's value function for $\left[X_{F}^{*}, \infty\right)$.

\subsection{Continuous-time $v s$ discrete-time games}

SROG are usually formulated in continuous-time ${ }^{16}$ and focused on symmetric and Markov equilibrium exercise strategies in which each firm's exercise strategy, conditional upon the other's exercise strategy, is value-maximizing. It is a Markov equilibrium in the sense that it is considered that the state of the decision process tomorrow is only affected by the state of the decision process today, and not by the other states before that.

In continuous-time games with an infinite horizon, the time index $t$, is defined in the domain $t \in[0, \infty)^{17}$. Given the strategies available and the relative values of the leader and the follower for a given current value $X(t)$, an equilibrium set of exercise strategies for each firm can be constructed. However, in sequential continuous-time ROG there is no definition for "the last period" and the "next period". This introduces potential time-consistency problems since it restricts the set of

\footnotetext{
${ }^{16}$ Some exceptions are Smit and Ankum (1993), Kulatilaka and Perotti (1998), Smit (2003), Murto et al. (2004) and Smit and Trigeorgis (2004, chapters 4, 5, 6 and 7), who use discrete-time frameworks.

${ }^{17}$ Notice that in ROG the focus of the analysis is directed not to the "timing strategy", chronologically speaking, but to the time at which the value of the investment reaches a threshold, regardless of at which chronological point in time that occurs. For mathematical convenience time is assumed to be infinite, although this assumption is not realistic for most investment projects.
} 
possible strategic game equilibria ${ }^{18}$. To overcome this problem, the F\&T (1985) results for deterministic game settings have been applied to continuous-time (pre-emption) ROG, sometimes, as highlighted by Thijssen et al. (2012), without a proper consideration of their appropriateness. Thijssen et al. (2012) show that it is often incorrect to exclude the scenario where both firms invest at the same time, and provide a more realistic ROG framework where the risk underlying strategic investment decisions is explicitly taken into account by the firms.

The formulation of firms' investment strategies in continuous-time is complex. Grenadier (2000, pp. xxi-xxvi) provides a heuristic version of the equilibrium exercise strategies for a duopoly ROG.

\section{ROG models}

The SROG branch of literature uses game theory concepts/assumptions that fit with those described in the introduction and an analytical formulation similar to that described in section 2. Its main contribution is the results and empirical support provided, or practical applications or the assumptions regarding the evolution process of the (mono) stochastic variable that drives the value of the investment, rather than the novelty of the game theory concepts or mathematical formulation used in the ROG model. NSROG uses game theory concepts or analytical formulations which diverge from those used in SROG, addressing critical issues as: (1) the degree of competition, or games with more than two firms, or the existence of exit-option(s), (2) asymmetries between firms, (3) games of asymmetric, or incomplete, or imperfect information, (4) cooperative games, (5) games where market sharing is dynamic, or (6) consideration of other factors not found in SROG.

\subsection{SROG models}

The literature combining the RO valuation technique with game theory concepts started with Smets (1993), who develops a RO model considering the trade-off between the option value of delaying a "foreign direct investment" ("FDI") and the value of investing first in a ex-ante symmetric duopolistic FDI market. Following Smets (1993), Dixit and Pindyck (1994, ch. 9) develop a basic ROG model for symmetric duopoly markets with a FMA.

Grenadier (1996) develops an equilibrium game framework for strategic RO exercise games for a symmetric duopoly market, suggesting a possible explanation for why some markets may experience building booms in the face of declining demand and property values. Huisman (2001) provides several innovative new technology adoptions leader-follower game models, adding to the

\footnotetext{
${ }^{18}$ For instance, the follower's strategy "invest immediately after the leader" cannot be accommodated. A rich literature on continuous-time games of timing, discussing this and other conceptual problems can be found in Kreps and Wilson (1982a,b), Dasgupta and Maskin (1986a,b), Simon and Stinchcombe (1989), Stinchcombe (1992), Bergin (1992), Bergin and McLeod (1993), Stenbacka and Tombak (1994), Dutta and Rustichini (1995), and Laraki et al. (2005).
} 
literature, among other contributions, the effect of technological uncertainty on firms investment behavior $^{19}$.

For a discrete-time framework, Smit and Ankum (1993) combine the RO approach of investment timing with basic principles of game theory and industrial organization, using standard game assumptions/formulation to illustrate the influence of competition on the project value and the investment timing. Smit (2003) focuses on the optional and strategic features of infrastructure investments to investigate his intuition that infrastructure investments generate other investment opportunities and, in doing so, change the strategic position of the firm.

These models provided the game theoretic/RO framework foundations to developing new NSROG models.

\subsection{NSROG models}

The discussion below focuses mainly on only critical game-theoretic or analytical formulation parts of each article, ignoring other possibly important aspects. We classify the RO models according to their relevant underlying game-theoretic aspects. Some articles provide clear contributions regarding more than one game-theoretic aspect and are, therefore, reviewed as belonging to more than one developing ROG models group. In the Appendix we provide the full characterization for each model.

\subsubsection{Degree of competition}

SROG assume that there is a simple duopoly and the leadership is exogenously determined or randomly chosen. This is characteristic of only a few industries.

$$
\text { i) } \mathbf{n}>\mathbf{2} \text { rivals }^{20,21}
$$

A natural development of ROG models, departing from Smets (1993), is the extension to markets with more than two firms. However, this imposes some challenges not only in the derivation of the firms' investment thresholds but also on the characterization of the entry-sequence/simultaneous equilibrium.

\footnotetext{
${ }^{19}$ Descriptions of SROG formulations can be found in Grenadier (2000a) who provides a summary of existing literature on game-theoretic option models, Grenadier (2000b) who illustrates how intersection of real options and game theory provides powerful insights into the behavior of economic agents under uncertainty, giving examples from real estate development in an oligopoly and oil exploration investment decisions with symmetric information. Smit and Trigeorgis (2004) provide several illustrations of model applications.

${ }^{20}$ In our classification " $n>2$ " is the ex-ante number of firms that are allowed to compete for the market revenues, not the number of firms that are allowed to invest. For instance, in complete preemption two-firm games there is no optimal investment time for the firm that is preempted -its payoff is nil. But the existence of the preempted firm affects the investment behavior of the firm that invests first.

${ }^{21}$ Other models such as those of Aguerrevere (2003, 2009), Grenadier (1999), Lambrecht (1999, 2001), Lambrecht and Perraudin (2003), Murto and Keppo (2002), Nielson (2002), Thissen (2004) and Anderson et al. (2010) also study ROG with more than two firms (see the Appendix). However, due to their other more relevant characteristics they are reviewed in other sections.
} 
Investments with more than two firms have been studied by Baldursson (1998) and Grenadier (2002) relying on the Leahy (1993) simplified myopic framework ${ }^{22}$. These papers are limited, however, to incremental investments given that the resolution of the equilibrium through the myopic strategy requires the assumption of infinitely divisible investment. Dynamic oligopoly markets with multiple lumpy investments have been studied by Gilbert and Harris (1984), Fudenberg and Tirole (1986) and Mills (1988), but for deterministic game settings with perfect foresight by the firms.

In the ROG literature there are two main approaches which consider more than two firms. One, followed, for instance, by Williams (1993) for the real estate market, is to assume that ex-ante there are $n$ symmetric firms, $n \in\{1, \ldots, \infty\}$, whose value depends on exogenous state variables and in equilibrium all firms invest at the same time as soon as a given threshold is reached. Another, followed by Bouis et al. (2009), is to assume that ex-ante there are more than two firms (three in this case) whose value depends on exogenous state variables but firms enter the market sequentially, providing analytical (or quasi-analytical) solutions for the investment thresholds of each firm. This latter approach seems more realistic, particularly for large oligopolies where the coordination for simultaneous investment is hardly feasible, but analytically very challenging as the number of firms grows.

Reiss (1998) and Armada et al. (2009) use frameworks that are slightly different from the two above. The former is a complete preemption ROG model that optimizes when identical firms should patent/adopt an innovation, where the arrival time of competitors is modeled as a Poisson process. The number of firms is not specified, but instead there is a constant hazard rate $\lambda d t$ which is regarded as a measure of the rivalry intensity. Armada et al. (2009) assume only two firms are allowed to invest, in a leader-follower setting, but the investment behavior of these firms is affected by an unspecified number of "hidden rivals" whose mean of probability of arrival is represented by a parameter $\lambda$, with $\lambda \in[0,1)$.

More specifically, Williams (1993) considers $n$ symmetric firms, $n \in\{1, \ldots, \infty\}$, in a real estate market where the aggregate demand $q$ and the supply by each developed asset are proportional to power functions of the current asset income $y: q=(x / y)^{\alpha}$, with $\alpha$ constant. The income $y$, with $y=x q^{-1 / \alpha}$, is related to an exogenous stochastic $(\mathrm{gBm})$ variable $x$ which affects demand. He provides the first rigorous derivation of a non-preemption Nash-equilibrium and an analytical solution for the optimal building rate where each firm $i$ (developer) conjectures correctly that each

\footnotetext{
${ }^{22}$ Leahy (1993) studied investment under uncertainty for perfect competition settings, demonstrating that a competitive firm invests at the threshold of a myopic firm.
} 
other firm currently builds at his optimal building rate $b_{m}^{*}$, with $m=1, \ldots, i-1, i+1, \ldots n$. Since the building rate $b^{*}$ can depend on the state variables $q$ and $x$, so each firm $n$ correctly anticipates in equilibrium that all other firms currently build at the aggregate rate: $b_{-i}^{*} \equiv \sum_{m \neq i} b_{m}^{*}$. Grenadier (2002) provides a tractable approach for deriving equilibrium investment strategies in a Cournot-Nash equilibrium for $n$ symmetric firms, with $n \in\{1, \ldots, \infty\}$. He assumes that the market inverse demand function is of a constant-elasticity form: $P(t)=X(t) \cdot Q(t)^{-1 / \gamma}$, where $\gamma>1 / n, \forall n$, to ensure that marginal profits are increasing in $X$, with $n \in\{1, \ldots, \infty\}$, and $X(t)$ is a multiplicative demand shock that evolves according to a gBm process. Firms produce a single, homogeneous and infinitely divisible output and can continuously invest in additional capacity to increase output by infinitesimal increments. Among other relevant contributions Grenadier examines the impact of competition on the investment option value and provides an explicit expression for the option premium (OP), expressed as a function of the number of competitors $(n): O P(n)=1 /(n \gamma-1)$. He shows (through numerical simulations) that competition drastically erodes the value of the option to wait and leads to investment at very near the zero NPV threshold. Considering $\gamma=1.5$, for perfect competition $(n \rightarrow \infty)$, the $O P(\infty) \rightarrow 0$, for monopolies $(n=1)$, the $O P(1)=2$ (i.e., the equilibrium occurs when the NPV is equal to $200 \%$ of the investment cost), for duopolies $(n=2)$, the $O P(2)=0.5$ (i.e., the equilibrium occurs when the NPV is $50 \%$ of the investment cost).

Bouis et al. (2009) find that in a market with three firms the investment timing of the first investor lies between the one and the two-firm case. More generally, they show that in equilibria where firms invest sequentially, the timing of the first investor in case of $n+2$ firms always lies between the timing of the $n$ and $n+1$ firm case. They conclude that increased competition can delay rather than hasten investment and that market entry occurs earlier when the number of anticipated market entrants is small. Following the Bouis et al. (2009) approach, Pereira and Rodrigues (2010) consider a non-zero sum game for markets with three firms but where the entry of the third firm (called second follower) expands the total market.

Murto et al. (2004) study a discrete-time state-space oligopoly game for homogeneous non-storable commodity markets, where the demand evolves stochastically and firms can make multiple lumpy investments in order to adjust their production cost functions or production capacities. They compare the case where firms invest identical lump sums with the case where one firm makes investments in larger lumps than the other firms, providing an illustration for the trade-off between flexibility and scale economies (in the sense that the firm with small investments is more flexible and the firm with larger investments is more cost-effective). In contrast to Williams (1993) and 
Grenadier (2002), firms are required to invest sequentially to ensure a Markov-perfect Nash equilibrium. Chevalier-Roignant and Trigeorgis (2010) also study lump investment decisions for oligopoly markets but in a continuous-time framework, where firms identify an opportunity to enter the market before it grows up to the point which justifies the entry cost. They show that in oligopoly markets, market entry involving lumpy investments takes place in sequence regardless of whether firms can observe their rivals' moves.

Odening et al. (2007) study investment decisions for perfect competition and demonstrate, using simulations, that myopic planning may lead to non-optimal investment strategies. Aguerrevere (2003) investigates the effect of competition on the dynamics of the price of a non-storable commodity considering incremental investment with time to build and operational flexibility. He shows that the effect of competition on properties of the endogenous output price is dramatic. Aguerrevere's framework differs from that used by Grenadier (2002) because it does not allow for flexibility in the use of the installed capacity and the resulting output price is the same regardless of the number of competitors. Aguerrevere (2009) examines how competition in the product market affects the relation between firms' investment decisions and their asset return dynamics, demonstrating that, when demand is low, firms in more competitive industries earn higher returns and, when demand is high, firms in more concentrated industries earn higher returns.

\section{ii) Exit options}

"Exit options" ("EO") are considered in a continuous-time framework for monopolies under uncertainty, by Dixit (1989), Alvarez $(1998,1999)$ and Sødal (2006), among others, and, in a determinist framework for duopolies, by Ghemawat and Nalebuff (1985) and Fudenberg and Tirole (1986). However, with very few exceptions, EO have been neglected in ROG. It is usually assumed that firms optimally enter the market when a given RO threshold is reached and operate afterwards forever. This is rarely the case in real-life where (permanent or temporary) "exit" is possible. Methodologically, the "exit option-real option games" literature is closely related to some literature on "stopping time games".

With the exceptions of Lambrecht (2001), Murto (2004), Ruiz-Aliseda (2013) and Goto et al. (2008), ROG models study entry and exit strategies in isolation, that is firms' entry/exit behavior does not consider the interaction between the two options. Lambrecht (2001) investigates the interaction between market entry, company foreclosure and capital structure in a duopoly, where firms are restricted to a single entry/exit trigger strategy (one-shot entry/exit game), and provides explicit entry and exit thresholds. He extends the standard exit model by allowing financially distressed firms to renegotiate their debt contracts through a one-off debt exchange offer. The 
model allows us to analyse the order in which firms go bankrupt within a given industry, and concludes that firms with high bankruptcy costs or with prospects of profit improvement can obtain larger negotiated reductions on their debt repayments.

Murto (2004) examines a declining duopoly market where firms consider exit, the profitability evolves according a $\mathrm{gBm}$ process, the decision to exit is irreversible and firms affect negatively each other so that both would benefit from the exit of the rival. In order to be active firms spend $I_{i}$ units of money per unit of time with $i \in\{1,2\}$ denoting the two firms. The profit flows for the monopoly and duopoly are given by $\pi_{i}^{M}=\Pi_{i}^{M}(X)-I_{i}=X M_{i}-I_{i}$ and $\pi_{i}^{D}=\Pi_{i}^{D}(X)-I_{i}=X D_{i}-I_{i}$, respectively, with $M$ and $D$ denoting constants subjected to $0<D_{i}<M_{i}$, respectively for the "monopoly" and the "duopoly". The exit threshold for a duopoly is $X_{i}^{D}=\left[\beta_{2}(r-\alpha)\right] /\left[D_{i}\left(\beta_{2}-1\right)\right]\left(I_{i} / r-U_{i}\right)$, where $\beta_{2}$ is given by Eq. (9) and $U_{i}$ is the cost of permanent exit for firm $i$. Murto finds that with a low degree of uncertainty there is a unique equilibrium where one of the firms always exits before the other, and, when uncertainty is increased, there may be another equilibrium with the order reversed, depending on the degree of asymmetry in the firm specific parameters.

Ruiz-Aliseda (2013) develops a "one-shot" entry/exit timing game model for a duopoly where firms have to decide at each instant whether to be in (if inactive) or out (if active) of a market that expands up to a random date and dies thereafter. He uses a timing game framework where firms are ex-ante asymmetric (i.e., investments are not equally recoverable). Among other relevant results, he finds that the destructive effect of the threat of pre-emption on option values is weak (or even totally eliminated) if the rival's commitment to remain active in the market after investing is not credible. Goto et al. (2008) provide a feasible exit for a follower when profitability or the market declines.

\subsubsection{Asymmetries between firms}

Most ROG assume that firms are ex-ante/ex-post symmetric, following Smets (1993). Smets' deterministic competition framework can, however, be easily adjusted to accommodate ex-post asymmetries between firms. There are several sources of RO value-related asymmetries between firms, such as different learning rates, organizational flexibility, liquidity constrains or benefits/losses from positive/negative externalities due to other firms investments, or different sunk/operating costs or combinations of several of these asymmetries ${ }^{23}$. Asymmetries between

\footnotetext{
${ }^{23}$ We define "asymmetric ROG" as a game where firms are ex-ante or ex-post asymmetric regarding any RO valuerelated variable, regardless of the type of game information structure (symmetric/asymmetric, complete/incomplete, perfect/imperfect) each firm faces.
} 
firms can exist ex-ante only (i.e., before investment), ex-post only (i.e., after investment), or ex-ante and ex-post, and can be temporary or permanent, with the same or a different size and nature, and modeled as an endogenous or a deterministic variable. We focus mainly on the asymmetries regarding the RO parameters and the formulation used to incorporate them into the ROG models.

Huisman (2001, ch. 8), develops a RO model for duopolies where firms face asymmetric costs in the adoption of a technology, and concludes that different equilibriums arise depending on the size of the cost asymmetry. Following a similar framework as that of Huisman (2001, ch. 8), but for a scenario where firms are ex-ante active, Pawlina and Kort (2006) study the impact of asymmetric investment costs on the optimal RO exercise strategies for a duopoly. The instantaneous profits of firm $i$, with $i \in\{1,2\}$, are represented by $\pi_{N_{i} N_{j}}(x)=x D_{N_{i} N_{j}}$, where $x$ follows a $\mathrm{gBm}$ process, $D_{N_{i} N_{j}}$ is a deterministic contribution to the profit function subjected to $D_{10}>D_{00}, D_{10}>D_{11}, D_{00}>D_{01}$ and $D_{11}>D_{01}$, which bound the competition conditions, $N_{k}$ equal to " 0 " or " 1 " if firm $k$ has not invested or firm $\mathrm{k}$ has invested, respectively, with $k \in\{i, j\}$. The cost asymmetry is introduced through $I_{2}=k I_{1}$ with $k \in(1, \infty)$ and $I_{1}$ and $I_{2}$ accounting for the investment cost of firms 1 and 2, respectively. They derive closed-form solutions for the leader and the follower for sequential investments, respectively $x_{i}^{F}=\beta_{1} /\left(\beta_{1}-1\right)\left[I_{1}(r-\mu)\right] /\left(D_{11}-D_{01}\right)$ and $x_{1}^{L}=\beta_{1} /\left(\beta_{1}-1\right)\left[I_{1}(r-\mu)\right] /\left(D_{10}-D_{01}\right)$, and a threshold for simultaneous investment, $x_{i}^{S}=\beta_{1} /\left(\beta_{1}-1\right)\left[I_{i}(r-\mu)\right] /\left(D_{11}-D_{00}\right)$. They demonstrate that there are three equilibrium strategies and critical levels of cost asymmetry which delineate the equilibrium regions as a function of the market variables. Armada et al. (2009) uses the same framework to consider a leader-follower investment cost asymmetry.

Kong and Kwok (2007) study for a duopoly the simultaneous effect of investment costs and revenue flow asymmetries. Smit and Trigeorgis (2004, ch. 7) analyse a duopoly two-stage game where firms choose output levels endogenously with possible asymmetric production costs. Carlson et al. (2012) study the simultaneous effect of asymmetric investment costs and salvage values. The incorporation of multiple ex-ante asymmetries between firms, although analytically challenging, provides a richer set of equilibrium strategies. Baba (2001) compares, for a duopolistic loan market, the firms' behavior when the leadership role is interchangeable (ex-ante symmetry) with when the leadership is deterministically assigned (ex-ante asymmetry), and concludes that, in the latter case, banks have a greater incentive to wait until the loan demand conditions improve sufficiently.

\subsubsection{Information structure (asymmetric/incomplete/imperfect)}


The assumption of symmetric, complete and perfect information is not realistic for most competitive investments since often firms' conjectures about rival behavior are incorrect. ROG with asymmetric, or incomplete, or imperfect information, relax the assumption that all firms are identically and fully informed about the current value and the future evolution pattern of the ROGrelated variables and the rival's reactions to their own actions. They specify, for each firm, the information structure under which it competes with the rivals. If a given game information structure is characteristic of one or few participants, the ROG is defined as an "asymmetric-incomplete (and possibly imperfect) information game". If it is equally shared by all the participants, it is defined as a "symmetric-complete-perfect information game" ${ }^{24}$.

Grenadier (1999) relaxes the RO standard assumption that timing the option exercise is simultaneous and uninformative and that agents are perfectly informed about the parameters of their opponents RO. He assumes that $n$-firms, $n \in[2, \infty)$, are imperfectly and asymmetrically informed and may impute the private information of others by observing their exercise (or lack of exercise) decisions. His results for the option exercise policies equilibrium provide insights into the patterns of exercise.

Following Grenadier (1999), but using a different payoff structure, Lambrecht and Perraudin (2003) develop a 2-firm model where firm $i$ can invest at cost $I_{i}$ in an income stream $x(t)$ whose evolutions follow Eq. (2), but, another firm $j$ may invest first, so $i$ loses any further opportunity to invest ${ }^{25}$. Firm $i$ conjectures that firm $j$ invests when $x(t)$ first crosses $\bar{x}_{j}$ and that $\bar{x}_{j}$ is an independent draw from a distribution $F_{j}\left(\bar{x}_{j}\right)$, with $F_{j}\left(\bar{x}_{j}\right)$ having continuously differentiable density $F_{j}^{\prime}\left(\bar{x}_{j}\right)$ with positive support on an interval $\left[\bar{x}_{L}, \bar{x}_{U}\right]$. Since firm $j$ invests only when $x(t)$ first crosses a threshold, $i$ learns about $j$ when $x(t)$ hits a new high within the support $F_{j}^{\prime}\left(\bar{x}_{j}\right)$. When this happens, if firm $j$ invests, $i$ learns that $j$ 's threshold level is the current $x(t)$. Conversely, if $j$ does not invest, firm $i$ learns that $j$ 's threshold lies in a higher range of $x$ values than it had previous believed (i.e., in $\left[\hat{x}_{t}, \bar{x}_{U}\right]$ where $\left.\hat{x}_{t} \equiv \max _{0 \leq \tau \leq t}\left\{x_{\tau}\right\}\right)$. Firm $i$ 's conditional conjecture about the distribution of $j$ 's threshold is: $F_{j}\left(\bar{x}_{j} \mid \bar{x}_{t}\right)=\left[F_{j}\left(\bar{x}_{j}\right)-F_{j}\left(\hat{x}_{t}\right)\right] /\left[1-F_{j}\left(\hat{x}_{t}\right)\right]^{26}$. The authors provide analytical results for complete pre-emption multi-firm equilibrium where the incomplete information is introduced by letting the $i$ th firm observe its own cost, $I_{i}$, when it knows only that $I_{j}$, with $j \neq i$, is an independent draw from a distribution $G(k)$, whose characteristics are similar to those described

\footnotetext{
${ }^{24}$ The distinction between incomplete and imperfect information is somewhat semantic (see Tirole (1988), p. 174, for more details). Both information structures are incorporated in ROG using similar mathematical formulations.

${ }^{25}$ This game can also be defined as a "winner-takes all" (WTA) game.

${ }^{26}$ This framework has the advantage of being easily extendable to games with more than two firms.
} 
above for $F_{j}\left(\bar{x}_{j}\right)$. The model predicts that equity returns of firms which hold RO and are subjected to pre-emption will contains jumps and positive skewness.

Murto and Keppo (2002) study a $n$-firm complete pre-emption game ${ }^{27}$ where firms compete with rivals for the same and unique project while monitoring the project value but being uninformed of their rivals valuations. They characterize a Nash equilibrium under different assumptions regarding the information that firms have about each other's valuation of the project: (i) firms know the value of each other's projects - complete information, and (ii) firms are uninformed of each others' projects valuation - incomplete information. Their results show that the assumption on the information each firm has on each others' valuation for the project has an important impact on the equilibrium of the investment game. When firms do not know each others' valuation for the project it is suggested they should assess the likelihood that a given competitor invests in the next time period, and, it is shown that under this assumption the investment triggers for the Nash equilibrium are between the perfect information equilibrium level and the optimal monopoly level.

Décamps and Mariotti (2004) develop a duopoly model where each firm is informed of its own investment cost, $I_{i}$, but not of the cost of the rival, which is independently drawn from a common knowledge distribution $G$ with the same characteristics as the distribution $F_{j}\left(\bar{x}_{j}\right)$ described above for Lambrecht and Perraudin (2003). For a risk-neutral world with discount rate $r>0$, there are two players $i=1,2$ who can invest in a project whose value is the same for both firms and is not affected by whom invests first. The project can be of high or low quality, with $p_{0} \in(0,1)$ denoting the prior probability that the project can be of low or high quality, and firms can learn about the quality of the project at no cost by observing the outcome of a public signal (surveys, investment reports, etc) modeled as a Poisson process $B$ with failure rate $\lambda^{B}>0$, if the project is of lowquality (LQ), and zero otherwise. Investment decisions are public and once a firm (leader) has invested, the rival (follower) receives more information about the project than that provided by the public signal. It is assumed that a high-quality (HQ) project never fails and generates a profit $d>0$ per unit of time, and a LQ project generates the same instantaneous profit but may fail according to a Poisson process with failure rate $\lambda^{L}>0$, after which the profit is zero. Failures of an installed project are independent from that generated by the public information signal and are perfectly observed by the follower. With this information structure, a HQ project generates discounted profits $h=d / r$ and a LQ project generates expected discount profits $l=d /\left(r+\lambda^{L}\right)$. They show that there

\footnotetext{
${ }^{27}$ A WTA game where when one of the firms invests the opportunity is eliminated for the other firms.
} 
is a unique (attrition game) symmetric equilibrium, which depends on the initial beliefs, and provide results for the impact of changes in the (asymmetric) cost and signal distributions on the optimal investment timing.

Hsu and Lambrecht (2007) examine the investment behavior of an incumbent and a potential entrant that compete for a patent. The incumbent is active producing one product protected infinitely by a patent. The challenger can enter the market by patenting a substitute for the incumbent's present product. The costs of acquiring the new patent are $I_{i}$ for the incumbent and $I_{e}$ for the entrant (possibly asymmetric). The challenger has complete information about the incumbent whereas the incumbent does not know the precise value of its opponent's investment cost. If the patent is acquired by the challenger the market structure will be a duopoly with two products, otherwise remains as monopoly with only one product. Before the second product is launched the incumbent makes a profit of $\pi_{1 i} x_{t}$ per unit of time, with $x$ following a $\mathrm{gBm}$ process. If it succeeds to acquire the new patent makes a profit of $\pi_{2 i} x_{t}$. If the new entrant acquires the new patent the incumbent's profits are $\delta_{i} x_{t}$, and the entrant will accumulate profits at the rate $\delta_{e} x_{t}$, where $\pi_{2 i}, \pi_{1 i}, \delta_{i}$ are profits parameters obeying the following relations, $\pi_{2 i}>\pi_{1 i}>\delta_{i}$. It is shown that the slightest possibility of pre-emption makes the informationally disadvantaged firm act at the pre-emption threshold.

Following Hsu and Lambrecht (2007), Graham (2011) develops a duopoly ROG model with asymmetric information concerning the revenue. In contrast with existing models, he shows that an equilibrium may not exist within the standard continuous framework if the private information is over the revenue. Leung and Kwok (2012) study a (two-stage) preemptive patent investment game where an incumbent firm competes with a potential entrant firm for the patent of a substitute product in a market with uncertain profits. The entrant has complete information on the commercialization cost of the incumbent and the incumbent only knows the commercialization cost distribution of the entrant. Their results show that the incumbent tends to act aggressively in response to its informationally disadvantaged status, and always suffers from a loss in its RO value while the RO value of the advantaged entrant may be undetermined or enhanced.

Watanabe (2010) studies a duopoly market where profit flows have two uncertain parameters, one known only by the incumbent and the other shared by both firms. The incumbent has a higher expected profit and, therefore, invests earlier than the potential entrant. Watanabe characterizes the equilibrium conditions for the incumbent. Anderson et al. (2010) study a $n$-firm, complete preemption game where firms have symmetric and complete information about the value of the 
investment opportunity $V$, whose evolution follows a $\mathrm{gBm}$ process, and each firm has private information about its rivals' (possible asymmetric) costs. Grenadier (2000a) provides several examples of different ROG and game information structures, and illustrations of their practical application.

\subsubsection{Cooperation between firms}

Most ROG models are developed for markets where cooperation is not allowed. However, often it is in the best interest of rivals to join forces and cooperate to share risks, restricting production or increasing prices. If cooperation is allowed the investment threshold points are chosen to maximize the sum of the firms' value functions. When cooperation is not allowed the investment thresholds points are chosen to maximize the value function of each firm, leading to PE, or WOA, or WTA games, where the reward from the investment is asymmetrically shared by the market rivals. Some $\mathrm{R} \& \mathrm{D}$ projects, or patents, new technology, or where there are networks or standardization externalities are natural areas where the cooperation strategy is followed. There are very few ROG models considering cooperation (see the Appendix).

Weeds (2002) uses a standard RO framework to derive the investment thresholds for a duopoly R\&D market where firms are allowed to plan their investments cooperatively. She derives the function of the combined value of the two firms for sequential (leader-follower) investments and provides the investment thresholds for both the cooperative and the non-cooperative scenarios. Her results show that the investment for the non-cooperative scenarios is more delayed than for the cooperative scenario. Boyer et al. (2010) studies capacity-building investments focusing on a riskneutral homogeneous (growing) duopoly product market with incremental indivisible capacity investments. Firms face an inverse demand function $P\left(t, X_{t}\right)=Y_{t} D^{-1}\left(X_{t}\right)$, where $X_{t} \geq 0$ is the aggregate output, $Y_{t} \geq 0$ is an industry $(\mathrm{gBm})$ random shock, and $D: \mathbb{R}_{+} \rightarrow \mathbb{R}_{+}$is a mapping describing the non-stochastic component of the market demand curve which is strictly decreasing, continuously differentiable and integrable on $\mathbb{R}_{+}$. The mapping $x \rightarrow x D^{-1}(x)$ is strictly concave on $[0, D(0)]$ and collusion is allowed for when firms are active. Among other relevant results they report that "Markov Perfect Equilibrium-tacit collusion" episodes may occur only at stages where both firms hold positive capacity (taking the form of postponed simultaneous investments) and are more likely to exist in highly volatile and/or faster growing markets and low cost of capital scenarios.

The models above are standard "one-shot" (investment cost) ROG. Weyant and Yao (2005) derive, however, a model for a duopoly market where firms make $R \& D$ investments on an ongoing 
(continuous) basis before the success of the project is known. They argue that this ongoing nature and the consequent repeated strategic interactions between firms may facilitate self-enforcement tacit collusion. Their results show that when the information time lag is sufficiently short, cooperative equilibrium emerges and the investment is delayed more than for the one-firm case. Garlappi (2004) provides a tractable discrete-time asset pricing model that takes into account the different sources of uncertainty embedded in the R\&D process and quantifies the effect of preemption on security prices and returns. He shows that the risk premia demanded by an ownership claim to competing $R \& D$ ventures increase when a rival pulls ahead in the race and are lower when rivals are closer to each other in the development process. Compared to the cooperative scenario, competition reduces the industry value and lowers the expected completion time for the project.

Thijssen (2004, ch. 6) studies the effect of spillovers in strategic cooperative situations. Although not formalized in a RO framework, his approach might facilitate considering the spillover effect on ROG. Li and Sick (2010) examine empirically the equilibrium of firms investment behavior for a market where output price and production volume are uncertain, there are economies of scale and cooperation is allowed (network effect). They show that the probability of cooperation is positively affected by the network effect and negatively affected by the real option exercise price.

\subsubsection{Market sharing}

Most ROG follow the Smets (1993) pre-emption game where the market shares of the leaderfollower are assumed to remain symmetric and static after the follower entry. However, firms often compete in rather different economic environments where (i) due to immediately patent or eventually brand dominance WTA, or (ii) there is a WOA so eventually one of the firms shrinks or disappears, or (iii) dominate shares are allocated dynamically over time among firms, or (iv) there are repeated cooperative games, where market shares are maintained through collusion. Few authors have considered dynamic market shares.

Grenadier (1996), Garlappi (2004), Murto and Keppo (2002), Weeds (2002) and Lambrecht and Perraudin (2003) study WTA games using a RO framework. Anderson et al. (2010) study complete pre-emption investment games based on auction and real options theory. Boyer et al. (2001) and Décamps and Mariotti (2004) study WOA real options games. These models characterize either WTA or WOA games where ex-post market shares are assumed to be static, i.e., after the last firm enters, firms will share a static (and possibly symmetric) proportion of the total market. For instance, the Bouis et al. (2009) 3-firm model assumes that the leader gets $100 \%$ of the market share if active alone, $50 \%$ of the market share if active with the (first) follower, and a constant and static one third of the market share as soon as the second follower invests. The Pereira and Rodrigues 
(2010) 3-firm model considers dynamic market share but in a pre-stage of the game only, where the entry of the third firm causes a market expansion with (possible) negative consequences on the market share of the rivals. Paxson and Pinto (2003) assume the market share evolves through the birth/death of customers, separately for the leader and the follower. Paxson and Melmane (2009) assume that the market share for search engines evolves deterministically, but is subject to synergy shocks from complementary activities.

\subsubsection{Other innovative Parameters}

There are several other models not included in the review above that, although some are SROG in terms of their underlying game-theoretic aspects, consider other interesting and innovative RO problems where (i) there are several factors determining the value underlying the option, or (ii) there are multiple-options, or (iii) uncertainty is firm-specific, or the stochastic processes exhibit positive/negative jumps, or firm profitabilities are correlated, or (iv) there are games between lenders and borrowers in restructuring debt.

(i) Most ROG models consider two-firms in a single factor single option game context, where the investment value uncertainty depends on a single $(\mathrm{gBm})$ variable. However, often the value of investment projects is simultaneously affected by the (possibly random) evolution of many factors such as output price and quantity, investment cost, operating cost, or technical and technological uncertainty, and, ex-ante, firms may hold more than one option. Paxson and Pinto (2005) consider a duopoly where the evolution of price and quantity follow independent (but possible correlated) processes. Huisman and Kort (2004) develop models for the optimization of new technology adoptions for duopolies where at the beginning of the game there is one technology available but the possibility of other technologies arriving in the near future. Huisman and Kort (2003) consider a duopoly where multiple technologies become available and the two firms have to optimize not only when to invest but also in which technology they should invest. Azevedo and Paxson (2011) study a duopoly where firms have two technologies available whose functions are complementary and, at the beginning of the game, each firm has the option to adopt one or both technologies, at the same time or at different times, in a context where both the evolution of the market revenues and the cost of the technologies evolve randomly. Mason and Weeds (2010) develop a model for a duopoly market where there is (a perhaps persistent) first-mover advantage and the return to investment depends on the number and sequence of investors, showing that both sequential and simultaneous investment behaviours are possible in equilibrium.

(ii) Nielson (2002) extends the duopoly result of Dixit and Pindyck (1994) for investments with positive externalities and considers the scenario where the monopolist has multiple investment 
opportunities. Murto et al. (2004) develops a discrete-time game for an oligopoly market where demand evolves stochastically and firms hold multiple investment opportunities to adjust their production cost functions or maximize capacity. Siddiqui and Takashima (2012) develop a sequential leader-follower two-stage ROG model for capacity expansion investments where there is knowledge spillover.

(iii) Thijssen (2010) studies a duopoly ROG where payoffs are driven by firm-specific (and possibly correlated) stochastic state variables. Thijssen (2012) examines pre-emption ROG where payoffs are strongly Markovian, providing results for contexts where payoffs are stochastic with positive jumps and a theorem that gives sufficient conditions that guarantee that the solution to an optimal stopping problem is of the trigger variety. Shackleton et al. (2004) study duopoly entry decisions where rivals earn different but correlated uncertain profitabilities from operating.

(iv) Ziegler (2004) uses game theory to study leverage and bankruptcy, following Leland (1994). There are several extensions of his approach, including foreclosures and debt renegotiation strategies. Sundaresan and Wang (2007) develop a framework to model the role of financial architecture on ex-ante growth option exercising decisions and firm value when debt offers tax benefits, and show that strong equity bargaining power lowers debt capacity, reduces firm value, and delays the exercise of growth options.

\section{Testable Hypotheses}

There are many testable hypotheses arising from the SROG and NSROG literature, although limited empirical testing or calibration of theoretical parameters to date. We have tried to imagine how to find the parameter values required for some NSROG, and note in the Appendix whether the respective authors provide any data or suggested sources for data. Some of the most common applications of SROG and NSROG are: "R\&D investments" (at a firm-level, patent race strategies, design of incentives for individual or groups of researchers, or allocation of funds among competing projects, and, at a country level, setting of innovation policies, tax incentives or direct subsidies); investment in new technologies (timing the adoption of new technologies in contexts where there are one or several technologies available, with or without technical and technological uncertainty, in markets with first or second mover advantages); "production capacity choices" (when to expand/reduce capacity); and "product design” types of buildings or locational FMA.

With the increasing sophistication of the information technologies and marketing monitoring techniques, frequent and public monitoring is today sometimes feasible, for instance in the cases of public marketing of innovations, FDA applications and patent applications. Progress on this 
monitoring area would allow the calibration of some SROG and NSROG models and the empirical test of hypotheses.

\section{A Program for DROGs in the Future}

The ROG models reviewed above address modern questions regarding investment decisions, provide new solutions to investment problems, and contribute to a better understanding of the complex nature of firms investment behavior in markets where uncertainty and competition prevail. SROG advances real option models beyond monopolies by considering investments by rival firms, which alter market share, product profitability or market size. Standard determination of leadership by artificial assumptions and simple pre-emption has been improved in some NSROG articles assuming asymmetric information structures, or ex-ante asymmetric market advantages.

The number of frameworks, techniques and theories combined with the real option theory has grown in the last two decades. The variety of assumptions made regarding the models underlying variables is now extensive, and the subsequent results vast and rich. ROG provide a credible investment analysis methodology which incorporates both uncertainty and competition, departing, therefore, from the classical investment appraisal techniques or real option models which make the unrealistic assumption that firms have a monopoly over investment decisions. Despite the shortfalls in ROG developments, and the current weaknesses underlying the literature available, we have now sounder models, better grounded in management intuition and economic theory, flexible and varied enough to incorporate a wide array of economic contexts.

\subsection{Six Suggested Improvements}

We suggest that ROG could be significantly improved through (i) benchmarking meta-analysis comparisons, (ii) empirical applications where there is reasonable macro empirical data, extended to areas where micro empirical parameter values can be calibrated, (iii) asymmetries identified and measured, (iv) guidance for instantaneous investment in continuous time, (v) exploring the often gray area between endogeneous and exogenous leadership, and (vi) clarifying the determinants of the leader or follower.

(i) We believe that a benchmarking empirical study, where the most relevant models from each group identified in section 3.2 are subjected to a parameter calibration and the results compared, would contribute significantly to future progress. Such research would be a key element to identifying incongruence areas, inaccuracies, unjustified disparities among models, successes and shortfalls within the ROG literature and, above all, define which research avenues should be

followed and which should be abandoned. Inevitably, in this journey there are shortfalls, such as 
the unacceptable and, perhaps, unjustified low number of empirical studies and the lack of benchmarking among ROG model results. Thus it is difficult to discuss, with some scientific basis, the value added and the progress made with the arrival of new models.

(ii) Without empirical work and comparison among the model results, the accumulation of a high number of models representing (small) improvements or extensions to the literature available may not represent the embedded value that we might expect, and risks increasing the complexity of models. For managing this "complexity versus accuracy problem" we suggest a division of the literature into two groups: (a) ROG models for use at macro-level, usually by governments to design/manage public policies, such as industry investment incentives, and tax, R\&D and subsidy policies and (b) ROG models used at micro-level in investment projects. Simplicity should be the role underlying the development of models for both groups, but very complex innovations/frameworks should be tested, preferably, in the former group first and, if feasible, extended then to the later.

(iii) This review organizes ROG models into game-theoretic related categories, a unique contribution. For each group identified in section 3.2, there is room for improvements, especially the models considering market "asymmetries" between firms and "asymmetric", or "incomplete" or "imperfect" game information. So far, with few exceptions, ROG models have addressed economic contexts where just one of the above NSROG assumptions holds.

(iv) ROG shares some of the not yet adequately addressed inconsistencies of continuous-time games such as "in continuous-time what does it mean to invest immediately after?" As highlighted by Thijssen et al. (2012) the application of the F\&T (1985) deterministic timing game results to continuous-time frameworks needs careful consideration. We should keep monitoring, and incorporating in ROG models, the future developments and progresses made on this regard in the literature on "continuous-time games of timing".

(v) Another issue in need of some clarification is the so called "endogenous" versus "exogenous" leadership. In our research we define the leadership as "exogenous" when firms strategies are "pure and exogenously set" (deterministic), and "endogenous" when firms strategies are either randomized, leading to Bayesian Nash-equilibrium as in Anderson et al. (2010), or the firm real option exercise (leadership) depends on the exercise strategies of all the real option holders. In the later case, firms optimal exercise strategies cannot be derived in isolation but as part of a game-theoretic equilibrium.

(vi) Some improvements may also be possible regarding whether "the roles of the leader and the follower" are interchangeable or predetermined. This is of particular importance to modeling, 
and must be defined accordingly, because, if the roles are predetermined, the follower cannot enter the market before the leader, and the leader recognizes the value of the option to wait from this source. In SROG models, the leadership in the investment is exogenously set and simultaneous moves are sometimes not allowed. The standard procedure consists of, firstly, finding a decision making rule for the follower assuming that the leader has already entered the market, and secondly, considering the entry decision of the leader taking into account of the ex-ante determined follower's response. This framework works well for duopolies, but, for investment contexts with more than two firms, and especially for perfect competition markets, the determination of the sequence by which firms invest is much more challenging. Solutions for this problem, so far, have relied on general frameworks like that of Leahy (1993), which have the disadvantage of determining the optimal investment behavior of all market players without specifying what they should do in case one, or several, players move first.

In the future, new and more sophisticated ROG models are expected. The "blank spaces" in the Appendix may be of some further help to guide researchers in developing improved ROG models. 


\section{References}

Aguerrevere, F., 2003. Equilibrium Investment Strategies and Output Price Behavior: A Real Options Approach. Review of Financial Studies 16 (4), 1239-1272.

Aguerrevere, F., 2009. Real Options, Product Market Competition and Asset Returns. Journal of Finance 64 (2), 957-983.

Alvarez, L., 1998. Exit Strategy and Price Uncertainty: a Greenian Approach, Journal of Mathematical Economics 29, 43-56.

Alvarez, L., 1999. Optimal Exit and Valuation under Demand Uncertainty: a Real Options Approach, European Journal of Operational Research 114, 320-329.

Anderson, S., Friedman, D., Oprea, R., 2010. Preemption Games: Theory and Experiment. American Economic Review 100 (4), 1778-1803.

Armada, M., Kryzanowski, L., Pereira, P., 2009. Optimal Investment Decisions for Two Positioned Firms Competing in a Duopoly Market with Hidden Competitors. European Financial Management 17, 305-330.

Azevedo, A., Paxson, D., 2011. Uncertainty and Competition in the Adoption of Complementary Technologies. Presented at the Real Options Conference 2011, Turku.

Baba, N., 2001. Uncertainty, Monitoring Costs, and Private Banks' Lending Decisions in a Duopolistic Loan Market: A Game-Theoretic Real Options Approach. Monetary and Economic Studies, May, 2146.

Baldursson, F., 1998. Irreversible Investment under Uncertainty in Oligopoly. Journal of Economic Dynamics and Control 22 (4), 627-644.

Bergin, J., 1992. A Model of Strategic Behavior in Repeated Games. Journal of Mathematical Economics 21, 113-153

Bergin, J., McLeod, W., 1993. Continuous Time Repeated Games. International Economic Review 34 (1), 21-37.

Bouis, R., Huisman, K., Kort, P., 2009. Investment in Oligopoly under Uncertainty: The Accordion Effect. International Journal of Industrial Organization 27 (2), 320-331.

Boyer, M., Lasserre, P., Moreaux, M., 2012. A Dynamic Duopoly Investment Game without Commitment under Uncertain Market Expansion. International Journal of Industrial Organization 30, pp. 663-681.

Carlson, M., Dockner, E., Fisher, A., Giammarino, R., 2012. Leaders, Followers, and Risk Dynamics in Industry Equilibrium. Journal of Financial and Quantitative Analysis, forthcoming.

Chevalier-Roignant, B., Trigeorgis, L., 2010. Market-Entry Sequencing under Uncertainty. Presented at the Real Options Conference 2010, Rome.

Chevalier-Roignant, B., Trigeorgis, L., 2011. Competitive Strategy: Options and Games. MIT Press.

Chevalier-Roignant, B., Flath, C., Huchzermeier, A., Trigeorgis, L., 2011. Strategic Investment under Uncertainty: A Synthesis. European Journal of Operational Research 215, 639-650.

Cottrell, T., Sick, G., 2002. Real Options and Follower Strategies: the Loss of Real Option Value to First-mover Advantage. Engineering Economist 47, 232-263.

Dasgupta, P., Maskin, E., 1986a. The Existence of Equilibrium in Discontinuous Economic Games, I: Theory. Review of Economic Studies 53 (1), 1-26.

Dasgupta, P., Maskin, E., 1986b. The Existence of Equilibrium in Discontinuous Economic Games, II: Applications. Review of Economic Studies 53 (1), 27-41.

Décamps, J., Mariotti, T., 2004. Investment Timing and Learning Externalities. Journal of Economic Theory $118(1), 80-112$. 
Dixit, A. 1989. Entry and Exit Decisions under Uncertainty. Journal of Political Economy 97 (3), 620638.

Dixit, A., Pindyck, R., 1994. Investments under Uncertainty. Princeton University Press.

Fudenberg, D., Tirole, J., 1985. Preemption and Rent Equalization in the Adoption of New Technology. Review of Economic Studies 52 (3), 383-401.

Fudenberg, D., Tirole, J., 1986. A Theory of Exit in Duopoly. Econometrica 54 (4), 943-960.

Garlappi, L., 2004. Risk Premia and Preemption in R\&D Ventures. Journal of Financial and Quantitative Analysis 39, 843-872.

Ghemawat, P., Nalebuff, B., 1985. Exit. RAND Journal of Economics 16 (2), 184-194.

Goto, M., Takashima, R., Tsujimura, M., and Ohno, T., 2008. Entry and Exit Decisions under Uncertainty in a Symmetric Duopoly. Presented at the Real Options Conference 2008, Rio de Janeiro.

Graham, J., 2011. Strategic Real Options under Asymmetric Information. Journal of Economic Dynamics and Control 35 (6), 922-934.

Grenadier, S., 1996. The Strategic Exercise of Options: Development Cascades and Overbuilding in Real Estate Markets. Journal of Finance 51 (5), 1653-1679.

Grenadier, S., 1999. Information Revelation through Option Exercise. Review of Financial Studies 12 (1), 95-129.

Grenadier, S., (ed.) 2000a. Game Choices: The Intersection of Real Options and Game Theory. Risk Books.

Grenadier, S., 2000b. Option Exercise Games: the Intersection of Real Options and Game Theory. Journal of Applied Corporate Finance 13 (2), 99-107.

Grenadier, S., 2002. Option Exercise Games: An Application to the Equilibrium Investment Strategies of Firms. Review of Financial Studies 15 (3), 691-721.

Hsu, Y., Lambrecht, B., 2007. Pre-emptive Patenting under Uncertainty and Asymmetric Information. Annals of Operations Research 151, 5-28.

Huisman, K., Kort, P., 2003. Strategic Investment in Technological Innovations. European Journal of Operational Research 144, 209-223.

Huisman, K., Kort, P., 2004. Strategic Technology Adoption taking into Account Future Technological Improvements: A Real Options Approach. European Journal of Operational Research 159, 705-728.

Huisman, K., Kort, P., Pawlina, G., Thijssen, J. 2004. Strategic Investment under Uncertainty: A Survey of Game Theoretic Real Options Models. Journal of Financial Transformation 13, 111-118.

Huisman, K.. 2001. Technology Investment: A Game Theoretic Real Options Approach. Kluwer Academic Publishers.

Kong, J., Kwok, Y., 2007. Real Options in Strategic Investment Games between Two Asymmetric Firms. European Journal of Operational Research 181 (2), 967-985.

Kreps, D., Wilson, R., 1982a. Sequential Equilibria. Econometrica 50 (4), 863-894.

Kreps, D., Wilson, R., 1982b. Reputation and Imperfect Information. Journal of Economic Theory 50, 863-894.

Kulatilaka, N., Perotti, E., 1998. Strategic Growth Options. Management Science 44 (8), 1021-1031.

Lambrecht, B., Perraudin, W., 2003. Real Options and Preemption under Incomplete Information. Journal of Economic Dynamics and Control 27, 619-643.

Lambrecht, B., 1999. Strategic Sequential Investments and Sleeping Patents. In: Brennan, M., Trigeorgis, L. (eds.), Project Flexibility, Agency, and Competition: New Developments in the Theory of Real Options, Oxford University Press, New York, pp. 297-323. 
Lambrecht, B., 2001. The Impact of Debt Financing on Entry and Exit in a Duopoly. Review of Financial Studies 14 (3), 765-804.

Laraki, R., Solan, E., Vieille, N., 2005. Continuous-Time Games of Timing. Journal of Economic Theory 120, 206-238.

Leahy, J., 1993. Investment in Competitive Equilibrium: The Optimality of Myopic Behavior. Quarterly Journal of Economics 108 (4), 1105-1133.

Leland, H., 1994. Corporate Debt Values, Bond Covenants and Optimal Capital Structure, Journal of Finance 49 (4), 1213-1252.

Leung, C., Kwok, Y., 2012. Patent-Investment Games under Asymmetric Information. European Journal of Operational Research 223, pp. 441-451.

Li, Y., Sick. G., 2010. The Equilibrium of a Real Options Bargaining and Exercise Game - Evidence from the Natural Gas Industry. Presented at the Real Options Conference 2010, Rome.

Mason, R., Weeds, H., 2010. Investment, Uncertainty and Pre-emption. International Journal of Industrial Organization 28 (3), 278-287.

Mills, D., 1988. Preemptive Investment Timing. RAND Journal of Economics 19 (1), 114-122.

Murto, P., Keppo, J., 2002. A Game Model of Irreversible Investment under Uncertainty. International Game Theory Review 4 (2), 127-140.

Murto, P., Näsäkkälä, E., Keppo, J., 2004. Timing of Investments in Oligopoly under Uncertainty: A Framework for Numerical Analysis. European Journal of Operational Research 157, 486-500.

Murto, P., 2004. Exit in Duopoly under Uncertainty. RAND Journal of Economics 35 (1), 111-127.

Nash, J., 1950. The Bargaining Problem. Econometrica 18 (2), 155-162.

Nash, J., 1953. Two-Person Cooperative Games. Econometrica 21 (1), 128-140.

Nielson, M., 2002. Competition and Irreversible Investments. International Journal of Industrial Organization 20, 731-743.

Odening, M., Mußhoff, O., Hirschauer, N., Balmann, A., 2007. Investment under Uncertainty - Does Competition Matter? Journal of Economic Dynamics and Control 31, 994-1014.

Pawlina, G., Kort, P., 2006. Real Options in an Asymmetric Duopoly: Who Benefits from Your Competitive Disadvantage? Journal of Economics \& Management Strategy 15 (1), 1-35.

Paxson, D., Melmane, A., 2009. Multi-factor Competitive Internet Strategy Evaluations: Search Expansion, Portal Synergies. Journal of Modeling Management 4 (3), 249-273.

Paxson, D., Pinto, H. 2003. Leader/follower Real Value Functions if the Market Share Follows a Birth/death Process. In Paxson, D. (ed.) Real R\&D Options. Butterworth-Heinemann, pp. 208-227.

Paxson, D., Pinto, H., 2005. Rivalry under Price and Quantity Uncertainty, Review of Financial Economics 14, 209-224.

Pereira, P., Rodrigues, A., 2010. Investment, Exogenous Entry and Expandable Markets under Uncertainty. Presented at the Real Options Conference 2010, Rome.

Reiss, A., 1998. Investment in Innovations and Competition: an Option Pricing Approach. Quarterly Review of Economics and Finance 38 (special issue), 635-650.

Ruiz-Aliseda, F., 2013. Entry and Exit in Duopoly under Uncertainty. Working Paper, Ecole Polytechnique, Paris.

Shackleton, M., Tsekrekos, A., Wojakowski, R., 2004. Strategic Entry and Market Leadership in a TwoPlayer Real Options Game, Journal of Banking and Finance 28, 179-201.

Simon, L., Stinchcombe, M.. 1989. Extensive Form Games in Continuous Time: Pure Strategies, Econometrica 57 (5), 1171-1214.

Siddiqui, A., Takashima, R., 2012. Capacity Switching Options under Rivalry and Uncertainty. European Journal of Operational Research 222, 583-595. 
Smets, F., 1993. Essays on Foreign Direct Investment. PhD thesis, Yale University.

Smit, H., Ankum, L., 1993. A Real Options and Game-Theoretic Approach to Corporate Investment Strategy under Competition. Financial Management 22 (3), 241-250.

Smit, H., Trigeorgis, L., 2004. Strategic Investment: Real Options and Games. Princeton University Press.

Smit, H., Trigeorgis, L., 2006. Real Options and Games: Competition, Alliances and Other Applications of Valuation and Strategy, Review of Financial Economics 15, 95-112.

Smit, H., 2003. Infrastructure Investment as a Real Options Game: The Case of European Airport Expansion. Financial Management, Winter, 5-35.

Sødal, S., 2006. Entry and Exit Decisions based on a Discount Factor Approach, Journal of Economic Dynamics and Control 30, 1963-1986.

Sparla, T., 2004. Closure Options in a Duopoly with Strong Strategic Externalities. Zeitschrift für Betriebswirtschaft 67, 125-155.

Stenbacka, R., Tombak, M., 1994. Strategic Timing of Adoption of New Technologies under Uncertainty. International Journal of Industrial Organization 12, 387-411.

Stinchcombe, M., 1992. Maximal Strategy Sets for Continuous-Time Game Theory. Journal of Economic Theory 56, 235-265.

Sundaresan, S., Wang, N., 2007. Investment under Uncertainty with Strategic Debt Service. American Economic Review 97 (2), 256-261.

Thijssen, J., Huisman, K., Kort, P., 2012. Symmetric Equilibrium Strategies in Game Theoretic Real Option Models, Journal of Mathematical Economics 48, 219-225.

Thijssen, J., 2004. Investment under Uncertainty, Coalition Spillovers and Market Evolution in a Game Theoretic Perspective. Kluwer Academic Publishers.

Thijssen, J., 2010. Preemption in a Real option Game with a First Mover Advantage and Player-Specific Uncertainty. Journal of Economic Theory 145, 2448-2462.

Thijssen, J., 2012. The Point of no Return: Equilibria in Continuous Time Preemption Games with Stochastic Payoffs. Working Paper, University of York.

Tirole, J., 1988. The Theory of Industrial Organization, MIT Press.

Tsekrekos, A., 2003. First-mover Advantages on the Strategic Exercise of Real Options. In: Paxson, D., (ed.) Real R\&D Options, Butterworth-Heinemann, pp. 185-207.

Watanabe, T., 2010. Real Options and Signaling in Strategic Investment Games. Presented at the Real Options Conference 2010, Rome.

Weeds, H., 2002. Strategic Delay in a Real Options Model of R\&D Competition. Review of Economic Studies 69, 729-747.

Weyant, J., Yao, T., 2005. Strategic R\&D Investment under Uncertainty in Information Technology: Tacit Collusion and Information Time Lag. Presented at the Real Options Conference 2005, Paris.

Williams, J., 1993. Equilibrium and Options on Real Assets, Review of Financial Studies 6 (4), 825-850.

Wu, J., 2006. Credible Capacity Preemption in a Duopoly Market under Uncertainty. Presented at the Real Options Conference 2005, Paris.

Ziegler, A., 2004. A Game Theory Analysis of Options: Corporate Finance and Financial Intermediation in Continuous Time. Springer. 
Appendix: Game Theory Aspects underlying the most Relevant Literature on Real Option Games.

Note:

$\# 1$ - we define a "one-shot" ROG as a game where firms hold a single option, as in Dixit and Pindyk (1994, ch. 9), and a "large" ROG as a game where firms hold more than one option, as in Ruiz-Aliseda (2013), or where the number of firms is large, as in Grenadier (1996, 2000a, 2002) and Aguerrevere (2003).

$\$ 2$ - we distinguish ROG where firms face the same market variables but are asymmetrically informed of their current value and/or future evolution (as in Decamp and Mariotti, 2004) from ROG where firms are asymmetrically affected by the same market variable(s) but symmetrically informed of such aspect of the game (as in Pawlina and Kort, 2006).

$\# 3$ - “ $n>2$ " means the ex-ante number of firms that are allowed to compete for the investment revenues, not the number of firms that are allowed to invest.

\begin{tabular}{|c|c|c|c|c|c|c|c|c|c|c|c|c|c|c|c|c|c|c|c|c|c|c|c|c|}
\hline \multirow{3}{*}{ Articles } & \multicolumn{2}{|c|}{ Formalism } & \multicolumn{5}{|c|}{ Game Information } & \multicolumn{13}{|c|}{ Type of ROG } & \multicolumn{3}{|c|}{ n (Firms) } & \multirow{3}{*}{$\begin{array}{l}\text { Industry or } \\
\text { Application(s) } \\
\text { (Suggested/used in } \\
\text { the article) }\end{array}$} \\
\hline & \multirow{2}{*}{$\begin{array}{l}\text { Discrete } \\
\text { Time }\end{array}$} & \multirow{2}{*}{$\begin{array}{l}\text { Continuous } \\
\text { time }\end{array}$} & \multirow{2}{*}{ Complete } & \multirow[t]{2}{*}{ Incomplete } & \multirow[t]{2}{*}{ Perfect } & \multirow[t]{2}{*}{ Imperfect Symmetric } & \multirow[t]{2}{*}{ Asymmetric } & \multirow{2}{*}{\multicolumn{2}{|c|}{ Simultaneous Sequential }} & \multirow{2}{*}{$\begin{array}{l}\text { One } \\
\text {-shot }\end{array}$} & \multirow{2}{*}{ Large } & \multirow{2}{*}{$\begin{array}{l}\text { Winner } \\
\text { Takes } \\
\text { All }\end{array}$} & \multirow{2}{*}{$\begin{array}{l}\text { Zero- } \\
\text { sum }\end{array}$} & \multirow{2}{*}{$\begin{array}{l}\text { Nonzero } \\
\text { sum }\end{array}$} & \multicolumn{2}{|c|}{\begin{tabular}{|l|} 
Time Horizon \\
\end{tabular}} & \multirow{2}{*}{ Cooperative } & \multirow{2}{*}{$\begin{array}{l}\text { Non } \\
\text { cooperative }\end{array}$} & \multirow{2}{*}{$\begin{array}{l}\text { Ex-ante } \\
\text { Symmetric }\end{array}$} & Ex-ante & 1 & 2 & $>2$ & \\
\hline & & & & & & & & & & & & & & & Finite & Infinite & & & & Asymmetric & & & & \\
\hline Aguerrevere (2003) & & $\mathrm{x}$ & $\mathrm{x}$ & & $\mathrm{x}$ & $\mathrm{x}$ & & $\mathrm{x}$ & $\mathrm{x}$ & $\mathrm{x}$ & $\mathrm{x}$ & & $\mathrm{x}$ & & & $\mathrm{x}$ & & $\mathrm{x}$ & $\mathrm{x}$ & & $\mathrm{x}$ & $\mathbf{x}$ & $\mathrm{x}$ & Manufacturing \\
\hline Aguerrevere (2009) & & $\mathrm{x}$ & $\mathrm{x}$ & & $\mathbf{x}$ & $\mathrm{x}$ & & $\mathbf{x}$ & $\mathbf{x}$ & & $\mathrm{x}$ & & $\mathrm{x}$ & & & $\mathrm{x}$ & & $\mathbf{x}$ & $\mathbf{x}$ & & & & $\mathrm{x}$ & Manufacturing \\
\hline Armada et al. (2009) & & $\mathrm{x}$ & $\mathrm{x}$ & & $\mathbf{x}$ & $\mathrm{x}$ & & & $\mathbf{x}$ & $\mathrm{x}$ & & & $\mathrm{x}$ & & & $\mathrm{x}$ & $\mathbf{x}$ & $\mathbf{x}$ & $\mathbf{x}$ & $\mathrm{x}$ & & & $\mathrm{x}$ & $\begin{array}{l}\text { Not } \\
\text { Specifyed }\end{array}$ \\
\hline Anderson et al. (2010) & & $\mathrm{x}$ & & $\mathbf{x}$ & $\mathbf{x}$ & $\mathbf{x}$ & & & $\mathbf{x}$ & $\mathbf{x}$ & $\mathrm{x}$ & $\mathbf{x}$ & $\mathbf{x}$ & & & $\mathrm{x}$ & & $\mathbf{x}$ & $\mathbf{x}$ & $\mathbf{x}$ & $\mathbf{x}$ & $\mathbf{x}$ & $\mathrm{x}$ & Mining \& Retailing \\
\hline Azevedo and Paxson (2011) & & $\mathrm{x}$ & $\mathrm{x}$ & & $\mathrm{x}$ & $\mathrm{x}$ & & & $\mathrm{x}$ & $\mathrm{x}$ & & & $\mathrm{x}$ & & & $\mathrm{x}$ & & $\mathrm{x}$ & $\mathbf{x}$ & & & $\mathbf{x}$ & & $\begin{array}{l}\text { New } \\
\text { Technology Adoptions }\end{array}$ \\
\hline Baba (2001) & & $\mathrm{x}$ & $\mathrm{x}$ & & $\mathbf{x}$ & $\mathrm{x}$ & & & $\mathbf{x}$ & $\mathbf{x}$ & & & $\mathrm{x}$ & & & $\mathrm{x}$ & & $\mathbf{x}$ & & $\mathbf{x}$ & & $\mathbf{x}$ & & Banking \\
\hline Bouis et al. (2009) & & $\mathrm{x}$ & $\mathrm{x}$ & & $\mathrm{x}$ & $\mathrm{x}$ & & $\mathrm{x}$ & $\mathbf{x}$ & $\mathrm{x}$ & & & $\mathrm{x}$ & & & $\mathrm{x}$ & & $\mathrm{x}$ & $\mathrm{x}$ & & & & $\mathrm{x}$ & $\begin{array}{l}\text { Not } \\
\text { Specifyed }\end{array}$ \\
\hline Boyer et al. (2012) & & $\mathbf{x}$ & & & $\mathbf{x}$ & $\mathbf{x}$ & & & $\mathrm{x}$ & $\mathbf{x}$ & & & $\mathbf{x}$ & & & $\mathbf{x}$ & $\mathbf{x}$ & $\mathbf{x}$ & $\mathbf{x}$ & & & $\mathbf{x}$ & & Manufacturing \\
\hline Carlson et al. (2012) & & $\mathrm{x}$ & $\mathrm{x}$ & & $\mathbf{x}$ & $\mathrm{x}$ & & & $\mathbf{x}$ & $\mathrm{x}$ & $\mathrm{x}$ & & $\mathrm{x}$ & & & $\mathrm{x}$ & & $\mathrm{x}$ & & $\mathrm{x}$ & & $\mathrm{x}$ & & Manufacturing \\
\hline Chevalier-Roignant et al. (2010) & & $\mathrm{x}$ & $\mathrm{x}$ & $\mathbf{x}$ & $\mathbf{x}$ & $\mathrm{x}$ & & $\mathrm{x}$ & $\mathbf{x}$ & $\mathrm{x}$ & & & $\mathrm{x}$ & & & $\mathrm{x}$ & & $\mathrm{x}$ & $\mathbf{x}$ & & & & $\mathrm{x}$ & $\begin{array}{l}\text { Not } \\
\text { Specifyed }\end{array}$ \\
\hline Cottrell and Sick (2002) & & $\mathrm{x}$ & $\mathrm{x}$ & & $\mathbf{x}$ & $\mathrm{x}$ & & & $\mathbf{x}$ & $\mathrm{x}$ & & & $\mathrm{x}$ & & & $\mathrm{x}$ & & $\mathrm{x}$ & $\mathbf{x}$ & & & $\mathbf{x}$ & & $\begin{array}{l}\text { Innovation Investment } \\
\text { projects }\end{array}$ \\
\hline Décamps and Mariotti (2004) & & $\mathrm{x}$ & & $\mathbf{x}$ & $\mathbf{x}$ & $\mathrm{x}$ & $\mathrm{x}$ & & $\mathbf{x}$ & $\mathrm{x}$ & & & $\mathrm{x}$ & & & $\mathrm{x}$ & & $\mathbf{x}$ & & & & $\mathbf{x}$ & & Not Specifyed \\
\hline Dixit and Pindyck (1994) & & $\mathrm{x}$ & $\mathrm{x}$ & & $\mathrm{x}$ & $\mathbf{x}$ & & & $\mathbf{x}$ & $\mathrm{x}$ & & & $\mathrm{x}$ & & & $\mathrm{x}$ & & $\mathbf{x}$ & $\mathbf{x}$ & & $\mathrm{x}$ & $\mathbf{x}$ & $\mathrm{x}$ & $\begin{array}{l}\text { Not specifyed } \\
\text { (Textbook) }\end{array}$ \\
\hline Garlappi (2004) & $\mathrm{x}$ & & $\mathrm{x}$ & & $\mathrm{x}$ & $\mathrm{x}$ & & & $\mathbf{x}$ & & $\mathrm{x}$ & $\mathrm{x}$ & $\mathrm{x}$ & & & $\mathrm{x}$ & $\mathrm{x}$ & $\mathbf{x}$ & $\mathrm{x}$ & & & $\mathbf{x}$ & & $\begin{array}{l}\text { Patent Races } \\
\text { R\&D ventures }\end{array}$ \\
\hline Goto et al. (2008) & & $\mathrm{x}$ & $\mathrm{x}$ & & $\mathrm{x}$ & $\mathrm{x}$ & & & $\mathbf{x}$ & & $\mathrm{x}$ & & $\mathrm{x}$ & & & $\mathrm{x}$ & & $\mathrm{x}$ & $\mathbf{x}$ & & & $\mathrm{x}$ & & Manufacturing \\
\hline Graham (2011) & & $\mathrm{x}$ & & $\mathrm{x}$ & & $\mathrm{x}$ & $\mathrm{x}$ & & $\mathrm{x}$ & $\mathrm{x}$ & & & $\mathrm{x}$ & & & $\mathrm{x}$ & & $\mathrm{x}$ & & $\mathrm{x}$ & & $\mathbf{x}$ & & $\begin{array}{l}\text { Not } \\
\text { Specifyed }\end{array}$ \\
\hline Grenadier (1996) & & $\mathrm{x}$ & $\mathrm{x}$ & & $\mathrm{x}$ & $\mathbf{x}$ & & $\mathrm{x}$ & $\mathrm{x}$ & $\mathbf{x}$ & & & $\mathrm{x}$ & & & $\mathrm{x}$ & & $\mathrm{x}$ & $\mathbf{x}$ & & & $\mathbf{x}$ & & Real Estate \\
\hline Grenadier (1999) & & $\mathrm{x}$ & $\mathrm{x}$ & $\mathrm{x}$ & & $\mathrm{x}$ & $\mathrm{x}$ & $\mathbf{x}$ & $\mathbf{x}$ & $\mathrm{x}$ & $\mathrm{x}$ & & $\mathrm{x}$ & & & $\mathrm{x}$ & & $\mathrm{x}$ & & $\mathrm{x}$ & & $\mathbf{x}$ & $\mathrm{x}$ & $\begin{array}{l}\text { Real Estate Oil well drilling } \\
\text { Pharmaceutical }\end{array}$ \\
\hline Grenadier (2000a) & & $\mathrm{x}$ & $\mathrm{x}$ & $\mathrm{x}$ & $\mathrm{x}$ & $\mathrm{x}$ & $\mathrm{x}$ & $\mathrm{x}$ & $\mathbf{x}$ & $\mathrm{x}$ & $\mathrm{x}$ & & $\mathrm{x}$ & & & $\mathrm{x}$ & & $\mathbf{x}$ & $\mathbf{x}$ & $\mathrm{x}$ & & $\mathrm{x}$ & $\mathrm{x}$ & $\begin{array}{l}\text { Not } \\
\text { Specifyed (Textbook) }\end{array}$ \\
\hline Grenadier (2000b) & & $\mathrm{x}$ & $\mathrm{x}$ & & $\mathrm{x}$ & $\mathrm{x}$ & & & $\mathbf{x}$ & & & & $\mathrm{x}$ & & & $\mathrm{x}$ & & $\mathbf{x}$ & $\mathbf{x}$ & & & $\mathbf{x}$ & & $\begin{array}{l}\text { Real Estate Oil well drilling } \\
\text { Pharmaceutical }\end{array}$ \\
\hline Grenadier (2002) & & $\mathbf{x}$ & $\mathbf{x}$ & & $\mathbf{x}$ & $\mathbf{x}$ & & $\mathrm{x}$ & $\mathrm{x}$ & $\mathrm{x}$ & $\mathbf{x}$ & & $\mathbf{x}$ & & & $\mathrm{x}$ & & $\mathrm{x}$ & $\mathbf{x}$ & & & & $\mathrm{x}$ & Real Estate \\
\hline Huisman (2001) & & $\mathrm{x}$ & $\mathrm{x}$ & & $\mathrm{x}$ & $\mathrm{x}$ & & $\mathrm{x}$ & $\mathbf{x}$ & $\mathrm{x}$ & & & $\mathrm{x}$ & & & $\mathrm{x}$ & & $\mathrm{x}$ & $\begin{array}{l}x \\
\text { ch. } 7,9\end{array}$ & $\begin{array}{l}x \\
\text { ch. } 8\end{array}$ & & $\mathbf{x}$ & & $\begin{array}{l}\text { New Technology Adoptions } \\
\text { (Textbook) }\end{array}$ \\
\hline Huisman and Kort (2004) & & $\mathrm{x}$ & $\mathbf{x}$ & & $\mathrm{x}$ & $\mathrm{x}$ & & & $\mathrm{x}$ & $\mathbf{x}$ & & & $\mathrm{x}$ & & & $\mathrm{x}$ & & $\mathrm{x}$ & $\mathbf{x}$ & & & $\mathbf{x}$ & & $\begin{array}{l}\text { New } \\
\text { Technology Adoptions }\end{array}$ \\
\hline Hsu and Lambrecht (2007) & & $\mathrm{x}$ & & $\mathrm{x}$ & & $\mathrm{x}$ & $\mathrm{x}$ & & $\mathrm{x}$ & $\mathrm{x}$ & & & $\mathrm{x}$ & & & $\mathrm{x}$ & & $\mathrm{x}$ & & $\mathrm{x}$ & & $\mathrm{x}$ & & Patent Race \\
\hline Kong and Kwok (2007) & & $\mathbf{x}$ & $\mathbf{x}$ & & $\mathbf{x}$ & $\mathbf{x}$ & & $\mathbf{x}$ & $\mathbf{x}$ & $\mathbf{x}$ & & & $\mathbf{x}$ & & & $\mathbf{x}$ & & $\mathbf{x}$ & & $\mathbf{x}$ & & $\mathbf{x}$ & & Not Specifyed \\
\hline
\end{tabular}




\begin{tabular}{|c|c|c|c|c|c|c|c|c|c|c|c|c|c|c|c|c|c|c|c|c|c|c|c|c|c|}
\hline \multirow{3}{*}{$\begin{array}{l}\text { Appendix, cont. } \\
\text { Articles }\end{array}$} & \multicolumn{2}{|c|}{ Formalism } & \multicolumn{6}{|c|}{ Game Information } & \multicolumn{13}{|c|}{ Type of ROG } & \multicolumn{3}{|c|}{ n (Firms) } & \multirow{3}{*}{$\begin{array}{l}\text { Industry or } \\
\text { Application(s) } \\
\text { (Suggested/used in } \\
\text { the article) }\end{array}$} \\
\hline & \multirow{2}{*}{$\begin{array}{l}\text { Discrete } \\
\text { time }\end{array}$} & \multirow{2}{*}{$\begin{array}{l}\text { Continuous } \\
\text { Time }\end{array}$} & \multirow{2}{*}{ Complete } & \multirow[t]{2}{*}{ Incomplete } & \multirow[t]{2}{*}{ Perfect } & \multirow{2}{*}{\multicolumn{2}{|c|}{ Imperfect Symmetric }} & \multirow{2}{*}{ Asymmetric } & \multirow{2}{*}{\multicolumn{2}{|c|}{ Simultaneous Sequential }} & \multirow{2}{*}{$\begin{array}{l}\text { One } \\
\text {-shot }\end{array}$} & \multirow{2}{*}{ Large } & \multirow{2}{*}{$\begin{array}{l}\text { Winner } \\
\text { Takes } \\
\text { All }\end{array}$} & \multirow{2}{*}{$\begin{array}{l}\text { Zero- } \\
\text { sum }\end{array}$} & \multirow{2}{*}{$\begin{array}{l}\text { Nonzero } \\
\text { sum }\end{array}$} & Time 1 & Horizon & Cooperative & Non & Ex-ante & Ex-ante & 1 & 2 & $>2$ & \\
\hline & & & & & & & & & & & & & & & & Finite & Infinite & & & & & & & & \\
\hline Kulatiliaka and Perotti (1998) & $x$ & & $x$ & & $\mathrm{x}$ & & $\mathrm{x}$ & & $x$ & $\mathrm{x}$ & $\mathrm{x}$ & & & $\mathrm{x}$ & & & $\mathrm{x}$ & & $\mathrm{x}$ & $\mathrm{x}$ & $\mathrm{x}$ & $x$ & $\mathbf{x}$ & & Standard Investment Projects \\
\hline Lambrecht (1999) & & $\mathrm{x}$ & $\mathrm{x}$ & & $\mathrm{x}$ & $\mathrm{x}$ & $\mathrm{x}$ & $\mathrm{x}$ & & $\mathrm{x}$ & $\mathrm{x}$ & & & $\mathrm{x}$ & & & $\mathrm{x}$ & & $\mathrm{x}$ & $\mathrm{x}$ & $\mathrm{x}$ & & $\mathrm{x}$ & $\mathrm{x}$ & $\begin{array}{l}\text { Patent Race } \\
\text { (published in a textbook) }\end{array}$ \\
\hline Lambrecht (2001) & & $\mathrm{x}$ & $\mathrm{x}$ & & $\mathrm{x}$ & & $\mathrm{x}$ & & & $\mathrm{x}$ & $\mathrm{x}$ & & & $\mathrm{x}$ & & & $\mathrm{x}$ & & $\mathrm{x}$ & $\mathrm{x}$ & & $\mathrm{x}$ & $\mathrm{x}$ & $\mathrm{x}$ & Banking \\
\hline Lambrecht and Perraudin (2003) & & $\mathrm{x}$ & & $\mathrm{x}$ & $\mathrm{x}$ & & $\mathrm{x}$ & $\mathrm{x}$ & & $\mathrm{x}$ & $\mathrm{x}$ & & $\mathrm{x}$ & $\mathrm{x}$ & & & $\mathrm{x}$ & & $\mathrm{x}$ & $\mathrm{x}$ & & & $\mathrm{x}$ & $\mathrm{x}$ & Retailing \\
\hline Leung and Kwok (2012) & & $\mathrm{x}$ & & $\mathrm{x}$ & & $\mathrm{x}$ & & $\mathrm{x}$ & & $\mathrm{x}$ & $\mathbf{x}$ & & & $\mathrm{x}$ & & & $\mathrm{x}$ & & $\mathrm{x}$ & & $\mathrm{x}$ & & $\mathrm{x}$ & & Patent Race \\
\hline Mason and Weeds (2010) & & $\mathrm{x}$ & $\mathrm{x}$ & & $\mathrm{x}$ & & $\mathrm{x}$ & & $\mathrm{x}$ & $\mathrm{x}$ & $\mathrm{x}$ & & & $\mathrm{x}$ & & & $\mathrm{x}$ & & $\mathrm{x}$ & $\mathrm{x}$ & & & $\mathrm{x}$ & & $\begin{array}{l}\text { Not } \\
\text { Specifyed }\end{array}$ \\
\hline Murto and Keppo (2002) & & $\mathrm{x}$ & $\mathrm{x}$ & $\mathrm{x}$ & $\mathrm{x}$ & & $\mathrm{x}$ & $\mathrm{x}$ & $\mathrm{x}$ & & $\mathrm{x}$ & & $\mathrm{x}$ & & & & $\mathrm{x}$ & & $\mathrm{x}$ & $\mathrm{x}$ & $\mathrm{x}$ & $\mathrm{x}$ & $\mathrm{x}$ & $\mathrm{x}$ & $\begin{array}{l}\text { Tele } \\
\text { communication }\end{array}$ \\
\hline Murto (2004) & & $\mathrm{x}$ & $\mathrm{x}$ & & $\mathrm{x}$ & & $\mathrm{x}$ & & $\mathrm{x}$ & $\mathrm{x}$ & $\mathrm{x}$ & & & $\mathrm{x}$ & & & $\mathrm{x}$ & & $\mathrm{x}$ & $\mathrm{x}$ & $\mathrm{x}$ & & $\mathrm{x}$ & & $\begin{array}{l}\text { Not } \\
\text { Specifyed }\end{array}$ \\
\hline Murto et al. (2004) & $\mathrm{x}$ & & $\mathrm{x}$ & & $\mathrm{x}$ & & $\mathrm{x}$ & $\mathrm{x}$ & $\mathrm{x}$ & & $\mathrm{x}$ & & & $\mathrm{x}$ & & & $\mathrm{x}$ & & $\mathrm{x}$ & $\mathrm{x}$ & & & & $\mathrm{x}$ & $\begin{array}{l}\text { Non-storable } \\
\text { Commodity }\end{array}$ \\
\hline Nielson (2002) & & $\mathrm{x}$ & $\mathrm{x}$ & & $\mathrm{x}$ & & $\mathrm{x}$ & & $\mathrm{x}$ & $\mathrm{x}$ & $\mathrm{x}$ & & & $\mathrm{x}$ & & & $\mathrm{x}$ & & $\mathrm{x}$ & & & & $\mathrm{x}$ & $\mathrm{x}$ & $\begin{array}{l}\text { Software } \\
\text { hardware }\end{array}$ \\
\hline Odening et al. (2007) & & $\mathrm{x}$ & $\mathrm{x}$ & & $\mathrm{x}$ & & $\mathrm{x}$ & & $\mathrm{x}$ & $\mathrm{x}$ & $\mathrm{x}$ & & & $\mathrm{x}$ & & & $\mathrm{x}$ & & $\mathrm{x}$ & $\mathrm{x}$ & & & & $\mathrm{x}$ & Agriculture \\
\hline Pawlina and Kort (2006) & & $\mathrm{x}$ & $\mathrm{x}$ & & $\mathrm{x}$ & & $\mathrm{x}$ & & $\mathrm{x}$ & $\mathrm{x}$ & $\mathrm{x}$ & & & $\mathrm{x}$ & & & $\mathrm{x}$ & & $\mathrm{x}$ & & $\mathrm{x}$ & & $\mathrm{x}$ & & $\begin{array}{l}\text { Not } \\
\text { Specifyed }\end{array}$ \\
\hline Paxson and Pinto (2005) & & $\mathrm{x}$ & $\mathrm{x}$ & & $\mathrm{x}$ & & $\mathrm{x}$ & & $\mathrm{x}$ & $\mathrm{x}$ & $\mathrm{x}$ & & & $\mathrm{x}$ & & & $\mathrm{x}$ & & $\mathrm{x}$ & $\mathrm{x}$ & & & $\mathrm{x}$ & & $\begin{array}{l}\text { Not } \\
\text { Specifyed }\end{array}$ \\
\hline Paxson and Melmane (2009) & & $\mathrm{x}$ & $\mathrm{x}$ & & $\mathrm{x}$ & & $\mathrm{x}$ & & & $\mathrm{x}$ & $\mathrm{x}$ & & & $\mathrm{x}$ & & & $\mathrm{x}$ & & $\mathrm{x}$ & $\mathrm{x}$ & & & $\mathrm{x}$ & & Internet \\
\hline Pereira and Rodrigues (2010) & & $\mathrm{x}$ & $\mathrm{x}$ & & $\mathrm{x}$ & & $\mathrm{x}$ & & & $\mathrm{x}$ & $\mathrm{x}$ & & & & $\mathrm{x}$ & & $\mathrm{x}$ & & $\mathrm{x}$ & $\mathrm{x}$ & & & & $\mathrm{x}$ & $\begin{array}{l}\text { Not } \\
\text { Specifyed }\end{array}$ \\
\hline Reiss (1998) & & $\mathrm{x}$ & $\mathrm{x}$ & & $\mathrm{x}$ & & & $\mathrm{x}$ & $\mathrm{x}$ & $\mathrm{x}$ & $\mathrm{x}$ & & & $\mathrm{x}$ & & & $\mathrm{x}$ & & $\mathrm{x}$ & & $\mathrm{x}$ & $\mathrm{x}$ & $\mathrm{x}$ & $\mathrm{x}$ & Patent Race \\
\hline Ruiz-Aliseda (2013) & & $\mathrm{x}$ & $\mathrm{x}$ & & $\mathrm{x}$ & & $\mathrm{x}$ & & & $\mathrm{x}$ & & $\mathrm{x}$ & & $\mathrm{x}$ & & & $\mathrm{x}$ & & $\mathrm{x}$ & & $\mathrm{x}$ & & $\mathrm{x}$ & & $\begin{array}{l}\text { Not } \\
\text { Specifyed }\end{array}$ \\
\hline Siddiqui and Takashima (2012) & & $\mathrm{x}$ & $\mathrm{x}$ & & $\mathrm{x}$ & & $\mathrm{x}$ & & & $\mathrm{x}$ & & $\mathrm{x}$ & & & $\mathrm{x}$ & & $\mathrm{x}$ & & $\mathrm{x}$ & $\mathrm{x}$ & & $\mathrm{x}$ & $\mathrm{x}$ & & $\begin{array}{l}\text { R\&D } \\
\text { Investment }\end{array}$ \\
\hline Shackleton et al. (2004) & & $\mathrm{x}$ & $\mathrm{x}$ & & $\mathrm{x}$ & & $\mathrm{x}$ & & & $\mathrm{x}$ & $\mathrm{x}$ & & & $\mathrm{x}$ & & & $\mathrm{x}$ & & $\mathrm{x}$ & $\mathrm{x}$ & $\mathrm{x}$ & & $\mathrm{x}$ & & Aircraft Industry \\
\hline Smets (1993) & & $\mathrm{x}$ & $\mathrm{x}$ & & $\mathrm{x}$ & & $\mathrm{x}$ & & & $\mathrm{x}$ & $\mathrm{x}$ & & & $\mathrm{x}$ & & & $\mathrm{x}$ & $\mathrm{x}$ & $\mathrm{x}$ & $\mathrm{x}$ & & & $\mathrm{x}$ & & $\begin{array}{l}\text { Not } \\
\text { Specifyed }\end{array}$ \\
\hline Smit and Ankum (1993) & $\mathrm{x}$ & & $\mathrm{x}$ & & $\mathrm{x}$ & & $\mathrm{x}$ & & $\mathrm{x}$ & $\mathrm{x}$ & $\mathrm{x}$ & & & $\mathrm{x}$ & & & $\mathrm{x}$ & & $\mathrm{x}$ & $\mathrm{x}$ & & & $\mathrm{x}$ & & $\begin{array}{l}\text { R\&D } \\
\text { Investment }\end{array}$ \\
\hline Smit (2003) & $\mathrm{x}$ & & $\mathrm{x}$ & & $\mathrm{x}$ & & $\mathrm{x}$ & & $\mathrm{x}$ & $\mathrm{x}$ & $\mathrm{x}$ & & & $\mathrm{x}$ & & & $\mathrm{x}$ & & $\mathrm{x}$ & $\mathrm{x}$ & & & $\mathrm{x}$ & & $\begin{array}{l}\text { Public Infrastructure } \\
\text { R\&D }\end{array}$ \\
\hline Smit and Trigeorgis (2004) & $\begin{array}{l}x \\
\text { ch. } 4,5,\end{array}$ & $\mathrm{x}$ & $\mathrm{x}$ & $\begin{array}{l}\mathrm{x} \\
\text { ch. } 9\end{array}$ & $\mathrm{x}$ & $\begin{array}{l}x \\
\text { ch. } 7,9\end{array}$ & $\mathrm{x}$ & $\begin{array}{l}\mathrm{x} \\
\text { ch. } 7,9\end{array}$ & & $\mathrm{x}$ & $\mathrm{x}$ & & $\begin{array}{l}\mathrm{x} \\
\text { ch. } 8\end{array}$ & $\mathbf{x}$ & & & $\mathrm{x}$ & $\begin{array}{l}\mathrm{x} \\
\text { ch. } 8\end{array}$ & $\mathrm{x}$ & $\mathrm{x}$ & & $\mathrm{x}$ & $\mathrm{x}$ & & $\begin{array}{l}\text { Electronics R\&D, Oil } \\
\text { (Textbook) }\end{array}$ \\
\hline Sparla (2004) & & $\mathrm{x}$ & $\mathrm{x}$ & & $\mathrm{x}$ & & $\mathrm{x}$ & & $\mathrm{x}$ & $\mathrm{x}$ & $\mathrm{x}$ & & & $\mathrm{x}$ & & & $\mathrm{x}$ & & $\mathrm{x}$ & $\mathrm{x}$ & $\mathrm{x}$ & & $\mathrm{x}$ & & Manufacturing \\
\hline Thijssen et al. (2010) & & $\mathrm{x}$ & $\mathrm{x}$ & & $\mathrm{x}$ & & $\mathrm{x}$ & & $\mathrm{x}$ & $\mathrm{x}$ & $\mathrm{x}$ & & & $\mathrm{x}$ & & & $\mathrm{x}$ & & $\mathrm{x}$ & $\mathrm{x}$ & $\mathrm{x}$ & & $\mathrm{x}$ & & $\begin{array}{l}\text { Not } \\
\text { Specifyed }\end{array}$ \\
\hline Tsekrekos (2003) & & $\mathrm{x}$ & $\mathrm{x}$ & & $\mathrm{x}$ & & $\mathrm{x}$ & & $\mathrm{x}$ & $\mathrm{x}$ & $\mathrm{x}$ & & & $\mathrm{x}$ & & & $\mathrm{x}$ & & $\mathrm{x}$ & $\mathrm{x}$ & & & $\mathrm{x}$ & & $\begin{array}{l}\text { Not } \\
\text { Specifyed }\end{array}$ \\
\hline Watanabe (2010) & & $\mathrm{x}$ & & $\mathrm{x}$ & $\mathrm{x}$ & & & $\mathrm{x}$ & & $\mathrm{x}$ & $\mathrm{x}$ & & & $\mathrm{x}$ & & & $\mathrm{x}$ & & $\mathrm{x}$ & & $\mathrm{x}$ & & $\mathrm{x}$ & & $\begin{array}{l}\text { Not } \\
\text { Specifyed }\end{array}$ \\
\hline Weeds (2002) & & $\mathrm{x}$ & $\mathrm{x}$ & & $\mathrm{x}$ & & $\mathrm{x}$ & & & $\mathrm{x}$ & $\mathrm{x}$ & & $\mathrm{x}$ & & & & $\mathrm{x}$ & $\mathrm{x}$ & $\mathrm{x}$ & $\mathrm{x}$ & & & $\mathrm{x}$ & & Patent Race \\
\hline Weyant and Yao (2005) & & $\mathrm{x}$ & $\mathrm{x}$ & & $\mathrm{x}$ & & $\mathrm{x}$ & & $\mathrm{x}$ & $\mathrm{x}$ & & $\mathrm{x}$ & & $\mathrm{x}$ & & & $\mathrm{x}$ & & $\mathrm{x}$ & $\mathrm{x}$ & & & $\mathrm{x}$ & & R\&D \\
\hline Williams (1993) & & $\mathrm{x}$ & $\mathrm{x}$ & & $\mathrm{x}$ & & $\mathrm{x}$ & & $\mathrm{x}$ & & $\mathrm{x}$ & & & $\mathrm{x}$ & & & $\mathrm{x}$ & & $\mathrm{x}$ & $\mathrm{x}$ & & $\mathrm{x}$ & $\mathrm{x}$ & $\mathrm{x}$ & Real Estate \\
\hline Wu (2006) & & $\mathrm{x}$ & $\mathrm{x}$ & & $\mathrm{x}$ & & $\mathrm{x}$ & & $\mathrm{x}$ & $\mathrm{x}$ & & $\mathrm{x}$ & & $\mathrm{x}$ & & & $\mathrm{x}$ & & $\mathrm{x}$ & $\mathrm{x}$ & & & $\mathrm{x}$ & & Manufacturing \\
\hline
\end{tabular}

